\title{
The Aftermarket \\ Performance of Initial \\ Public Offerings in Canada
}

Maher Kooli, Jean-Marc Suret

\begin{tabular}{c}
\hline Série Scientifique \\
Scientific Series
\end{tabular}

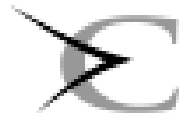

Montréal

Septembre 2001 


\section{CIRANO}

Le CIRANO est un organisme sans but lucratif constitué en vertu de la Loi des compagnies du Québec. Le financement de son infrastructure et de ses activités de recherche provient des cotisations de ses organisationsmembres, d'une subvention d'infrastructure du ministère de la Recherche, de la Science et de la Technologie, de même que des subventions et mandats obtenus par ses équipes de recherche.

CIRANO is a private non-profit organization incorporated under the Québec Companies Act. Its infrastructure and research activities are funded through fees paid by member organizations, an infrastructure grant from the Ministère de la Recherche, de la Science et de la Technologie, and grants and research mandates obtained by its research teams.

\section{Les organisations-partenaires / The Partner Organizations}

-École des Hautes Études Commerciales

-École Polytechnique

-Université Concordia

-Université de Montréal

-Université du Québec à Montréal

-Université Laval

-Université McGill

-Ministère des Finances du Québec

-MRST

-Alcan inc.

-AXA Canada

-Banque du Canada

-Banque Laurentienne du Canada

-Banque Nationale du Canada

-Banque Royale du Canada

-Bell Québec

-Bombardier

-Bourse de Montréal

-Développement des ressources humaines Canada (DRHC)

-Fédération des caisses Desjardins du Québec

-Hydro-Québec

-Industrie Canada

-Pratt \& Whitney Canada Inc.

-Raymond Chabot Grant Thornton

-Ville de Montréal

(C) 2001 Maher Kooli et Jean-Marc Suret. Tous droits réservés. All rights reserved.

Reproduction partielle permise avec citation du document source, incluant la notice $\odot$.

Short sections may be quoted without explicit permission, if full credit, including $\odot$ notice, is given to the source.

Ce document est publié dans l'intention de rendre accessibles les résultats préliminaires

de la recherche effectuée au CIRANO, afin de susciter des échanges et des suggestions.

Les idées et les opinions émises sont sous l'unique responsabilité des auteurs, et ne représentent pas nécessairement les positions du CIRANO ou de ses partenaires.

This paper presents preliminary research carried out at CIRANO and aims at encouraging discussion and comment. The observations and viewpoints expressed are the sole responsibility of the authors. They do not necessarily represent positions of CIRANO or its partners. 


\title{
The Aftermarket Performance of Initial Public Offerings in Canada*
}

\author{
Maher Kooli ${ }^{\dagger}$, Jean-Marc Suret ${ }^{\ddagger}$
}

\section{Résumé / Abstract}

La présente étude contribue à l'analyse internationale de la performance à long terme des émissions initiales, menée dans différents pays, en analysant les émissions canadiennes de la période 1992-1998. Nous examinons en particulier dans quelle mesure le choix des mesures de performance influence à la fois l'amplitude des résultats et la puissance des tests statistiques, comme l'affirment plusieurs auteurs tels Mitchell and Stafford (2000), Loughran and Ritter (2000) ainsi que Brav, Geczy et Gompers (2000). L'échantillon inclut 445 émissions initiales réalisées entre janvier 1991 et décembre 1991. Lorsque la méthode des résidus cumulés est utilisée pour mesurer la performance anormale, nous observons que les émissions initiales canadiennes ont une performance significativement inférieure à celle d'entreprises pairées, de taille semblable qui n’ont pas procédé à des émissions. Les résidus moyens pondérés calculés après 3 ou 5 ans sont négatifs lorsque ces rendements sont pondérés par les valeurs des produits bruts. L'effet n'est donc pas imputable uniquement aux petites émissions. Lorsque la méthode de la détention passive est utilisée, nous estimons la perte de richesses des acquéreur des émissions qui les détiennent pendant 5 ans à 24,66\% de leur richesse initiale. L'examen des facteurs explicatifs de la performance à moyen et long terme semble confirmer l'hypothèse des fenêtres d'opportunité, alors que les hypothèses basées sur l'irrationalité ou la sur réaction ne semblent pas confirmées.

In this paper, we empirically investigate Canadian initial public offerings (IPOs) to provide one case on the international evidence on the long-run performance of IPOs. Specifically, we examine whether the choice of a performance measurement methodology directly determines both the size and power of statistical test, as documented in previous studies (Mitchell and Stafford, 2000; Loughran and Ritter, 2000; and Brav, Geczy and Gompers, 2000). Our sample consists of 445 IPOs between January 1991 and December 1998. Using cumulative abnormal returns as an abnormal performance measure, we find that the Canadian IPOs underperform significantly the sample of seasoned firms with the same market capitalization. More specifically, the 3 year and the 5 year

\footnotetext{
* Corresponding Author: Jean-Marc Suret, CIRANO, 2020 University Street, 25 ${ }^{\text {th }}$ floor, Montréal, Qc, Canada H3A 2A5 Tel.: (514) 985-4000 Fax: (514) 985-4039 email: jean-marc.suret@fsa.ulaval.ca We are grateful to participants of the 2001 International Conference in Finance (Namur, June 2001) for helpful comments and suggestions. Financial support of the SSRH (Grant 67816) is gratefully acknowledged.

$\dagger$ CIRANO

$\ddagger$ Université Laval and CIRANO
} 
underperformances estimated on value weighted (VW) basis are statistically significant. Moreover, using the buy-and hold returns as an alternative measurement for long-run performance, we find that investors who buy immediately after listing and hold shares for five years will make a loss of $24,66 \%$, on equally weighted (EW) basis $(15,16 \%$ on $V W$ basis) relative to an investment in the control firms. Using the calendar-time returns method, we find that the 5 years underperformance is $-25,6 \%$ on EW basis $(-19,22 \%$ on VW basis). We have entertained a number of possible explanations for the poor subsequent performance of issuing firms. While, the fads or investor's overreactions and divergence of opinions hypotheses do not apply in explaining the aftermarket performance of Canadian IPOs, our evidence is consistent with the hot issue market story.

Mots Clés : Émissions initiales, sous performance à long terme, Canada

Keywords: Initial public offerings; long term performance; Canada 


\section{Introduction}

A large volume of research has demonstrated that investors purchasing initial public offerings (IPOs) of common stocks earn a large positive abnormal return in the early aftermarket period. However, researchers have documented that the gains from early price appreciation are not sufficient to compensate the losses that occur throughout subsequent price declines.

Ritter (1991) finds a significant mean market-adjusted return of $-29,13 \%$ at the end of the third year following the offering for a sample of 1,526 IPOs over the period from 1975 to 1984. Further, Ritter (1991) reports that the underperformance is concentrated among younger firms and firms that went public in the heavy-volume years. Indeed, for more established firms going public, and for those that went public in the light-volume years of the mid and late 1970's, there is no long run underperformance. IPOs that are not associated with venture capital financing, and those not associated with high-quality investment bankers, also tend to do especially poorly. These findings are in conformity with Loughran and Ritter (1995) who, for 4,753 U.S companies going public in the period from 1970 to 1990, document the underperformance of IPOs relative to seasoned firms with the same market capitalization. Aggarwal and Rivoli (1990) similarly find negative aftermarket performance of $-13,73 \%$ in the first year following the initial offering for 1,435 IPOs in the period from 1977 to 1987. However, the underperformance of new issues in the aftermarket has not been documented in all studies and the international evidence is varied (Loughran et al. (1994)). These international variations are due, in part, to the differences in regulations, contractual mechanisms, and characteristics of companies going public (Firch, 1997). Further research on the long-term stock return performance of IPOs and in different market settings seems warranted.

The purpose of this paper is to investigate the long run stock price behaviour of unseasoned new issues (IPOs) in Canada. The Canadian environment is interesting because a large number of the quoted companies are relatively small. Furthermore, the institutional characteristics of the Canadian market allow for an independent test of the most well-known issues in the US literature. Canadian IPOs are still uncovered by researchers. It is also important to study the performance of the IPOs in the long run. As Ritter (1991) points out, if systematic price patterns exist in the long run, then this raises questions concerning aftermarket efficiency. Moreover, we should know why investors are still buying IPOs stocks if they will loose in the long-run. Recently, many researchers such as Brav, Geczy and Gompers (2000), Brav and Gompers (1997) and Barber and Lyon (1997), have debated the approaches to the long run performance measurement and have examined the possible existence of a distinct performance anomaly. These authors argue that the choice of a performance measurement methodology directly determines both the size and the power of a statistical test and they have criticized the results of many previous studies. The IPO market is in continuous mutation considering the introduction of new mechanisms (Direct initial offerings, Dutch auctions, Internet auctions) ${ }^{1}$. In this context, if the underpricing or the high initial return is still a mystery, then the aftermarket underperformance is an even bigger one.

\footnotetext{
${ }^{1}$ See Biais and Faugeron (2000)
} 
Our sample consists of 445 IPOs for the period from 1991 to 1998 . We use three methodologies to analyse the relative performance of IPOs. Using cumulative abnormal returns as an abnormal performance measure, we find that the Canadian IPOs underperform significantly compared to the sample of seasoned firms with the same market capitalization. The underperformances for 36 and 60 month periods are statistically significant (on value weighted basis). Moreover, using the buy-and-hold returns as an alternative measurement for long-run performance, we find that investors who buy immediately after listing and hold their shares for five years, will make a loss of $24,66 \%$ (on equally weighted basis), as opposed to a $15,16 \%$ loss (on value weighted basis) relatively to an investment in the control firms. Using the calendar-time returns method, we found that the 5 years underperformance of the IPOs is $-25,6 \%$ (on equally weighted basis) and $-19,22 \%$ (on value weighted basis). When the sample is segmented by industry, we notice that the long-run performance of IPOs varies widely in different industries. Mining, oil \& gas and technology issues show poorer performances than those of other sectors. We have entertained a number of possible explanations for the poor subsequent performance of issuing firms. While, the fads or investor's overreaction and divergence of opinions hypotheses do not apply in explaining the aftermarket performance of Canadian IPOs, our evidence is fitting with a market where firms take advantage of windows of opportunity by issuing equity during periods where the price/earning ratio is high.

The remainder of this paper is organized as follows. Section 1 reviews some of the international literature on IPO stock market performances and underlines some reasons for the aftermarket underperformance and the international variations in observed performances. We also discuss the methodological dimension of measuring the aftermarket performance. Section 2 describes the data and the methodology used in the empirical investigation. Evidence on aftermarket underperformance is presented in the section 3. We also present the cross-sectional patterns and the results of multiple regression tests. Section 4 summarizes the findings and provides concluding remarks.

\section{Aftermarket performance: theoretical and methodological reasons}

\section{1- Prior research}

While there is a consensus that average initial underpricing should and does exist in the IPO market (see table 1), the aftermarket performance provides conflicting findings with some studies indicating negative, positive or even zero aftermarket performance. In an early study, Ibbotson (1975) does not reject the hypothesis that the abnormal returns in the aftermarket are zero. Recently, Paudyal et al.(1998) have reported that the performance of IPOs in Malaysia is not different from the performance of the market portfolio; the IPOs with higher initial return underperform compared to the market while those with low initial return outperform the market. In addition, they found that the long-term performance of IPOs is positively related to the reputation of the underwriters. If these results are confirmed, the underpricing will explain the 
underperformance of IPOs ${ }^{2}$. Buser and Chan (1987) report positive risk-adjusted returns $(11,2 \%)$ in the two years after listing for their sample of 1,078 NASDAQ stocks in the period from 1981 to 1985. Jacquillat and al.(1978) report positive aftermarket returns to IPOs in France during the period from 1966 to 1974. Kim and al. (1995) find that Korean IPOs outperform seasoned firms with similar characteristics. They sustained that "high causality bias" explains the aftermarket underperformance observed in the U.S. and other international findings. For example, about $17 \%$ of the sample firms in Ritter (1991) experienced subsequent changes in listing details. The bias is even more severe according to Levis (1993) who reports that 30\% of IPOs were de-listed within a 3-year period following their initial listing in the U.K.. Kim and al. (1995) also report that the large degree of underpricing in Korea may explain their results. If they exclude the first month return, they find that the Korean IPOs are characterized by neither over-performance nor underperformance when compared to seasoned firms.

Negative aftermarket returns for IPOs have been reported by Ritter (1991), Aggarwal and Rivoli (1990), Loughran and Ritter (1995), Levis (1993), Aggarwal, Leal and Hernandez (1993), and Firth (1997). Levis (1993) reports long-run underperformance of $-22.96 \%$ by the third year after the offering in the UK for 712 IPOs between 1980-1988. Aggarwal, Leal and Hernandez (1993) report three-year market-adjusted returns of $-47 \%,-19.6 \%$ and $-23.7 \%$ for Brazil, Mexico and Chile, respectively. Firth (1997) finds that, in average, the new issues in New Zealand underperform the market significantly and the level of long term underperformance is considerably related to profit forecast accuracy, corporate earnings and cash flows, and the growth rate.

Brav and Gompers (1997) compared the performance of venture and non-venture capital-backed IPOs to various benchmarks and found that matching IPOs to similar size and book-to-market firms eliminated the underperformance reported by Loughran and Ritter (1995). They also suggest that we should look more broadly at the types of firms that underperform and not treat IPO firms as a different group. Studies in Australia (Finn and Higham, 1988), Germany (Uhler, 1989), and Hong Kong (McGuinness, 1993) all reported negative aftermarket performance but the abnormal returns they found did not achieve statistical significance, so this is an evidence of market efficiency in the aftermarket. Clearly, there are international variations in observed performance and further research seems warranted. These international variations are due, in part to the contractual mechanisms and characteristics of companies going public, which are related to the reasons of the aftermarket underperformance. They are also due to the choice of a performance measurement methodology which directly determines both size and power of the statistical test ${ }^{3}$. These methodological measurements are discussed following the reasons of the underperformance.

\footnotetext{
${ }^{2}$ To separate the short-run phenomenon and the underperformance, it seems important to consider the performance of IPOs from the issue price and from the closed price of the first day.

${ }^{3}$ Ritter (1991) suggests that the selection of a benchmark portfolio, the length of the period over which the performance is measured, and the sample selection criterion might explain the differences in observed performances.
} 


\section{2- Reasons for the aftermarket underperformance}

Theoretical explanations for the long-run underperformance of IPOs are less than abundant. Aggarwal and Rivoli (1990) establish the possibility that the aftermarket is not immediately efficient in valuing newly issued securities and that the abnormal returns that ensue to IPO investors are the result of a temporary overvaluation by investors in the early trading. This is consistent with the "impresario" hypothesis or the fads ${ }^{4}$ hypothesis (Shiller (1990) and Debondt and Thaler $(1985,1987)$ ), which argues that the market for IPOs is subject to fads and that IPOs are underpriced by the investment bankers (the impresarios) to create the appearance of excess demand, just as the promoter of a rock concert attempts to make it an "event". This hypothesis predicts that: the greater the initial return at the IPO date, the greater the degree of subsequent correction of overpricing by investors will tend to be and the lowest subsequent returns should be.

Miller (1977 and 2000) confirm the divergence of opinion hypothesis to explain the underperformance of IPOs. He suggested that the investors who are most optimistic about an IPO will be its buyers. If there is a great deal of uncertainty about the value of an IPO, there will be differences of opinion between the optimistic and the pessimistic investors. As the information flows increase with time, the divergence of expectations decreases and thus the prices are adjusted downwards. Miller predicts that the greater the initial divergence of opinion and uncertainty, and the greater the diminution over time are, the more the security should underperform the market. To test this hypothesis we expect to see a negative relation between the ex-ante uncertainty and the aftermarket performance. One proxy for ex-ante uncertainty is size. For small firms with little or no operating history it seems clear that there would be a great deal of uncertainty. The age of the firm and of the industry would be other plausible proxies.

Ritter (1991) and Loughran and Ritter (1995) confirm the windows of opportunity hypothesis to explain the aftermarket underperformance. This hypothesis predicts that firms going public in high volume periods are more likely to be overvalued than the other IPOs. This has the testable implication that the high-volume periods should be associated with the lowest long-run returns. This pattern exists indeed in U.S.. Loughran and Ritter (1995) affirmed that, for IPOs, the prior rapid growth of many of the young companies makes it easy to justify high valuations by investors who want to believe that they have identified the next Microsoft.

Jain and Kini (1994, p. 1740) point out that the "successful timing or window-dressing actions taken by issuers may result in potential investors having high, and systematically biased, expectations of earnings growth in the post-issue period". These authors found that IPO firms exhibit a decline in post-issue operating performance in comparison to their pre-IPO levels. This declining can be attributed to the reduction in management ownership that occurs when a firm goes public, which is likely to lead to the agency problem described in Jensen and Meckling (1976).

\footnotetext{
${ }^{4} \mathrm{~A}$ fad is defined to be a temporary overvaluation caused by over-optimism on the part of investors. Fads are more likely to occur for less certain stocks or stocks held by "noise traders" (Camerer, 1989).
} 
Teoh, Welch, and Wong (1998) show that IPO underperformance is positively related to the size of discretionary accruals in the fiscal year of the IPO. They document that investors may misinterpret high earnings reported at the time of the offering, and consequently overvalue the new issues. Then, when high pre-issue earnings are not sustained, disappointed investors revalue the firm downwards. This scenario suggests that issuers have unusually high income-increasing accounting adjustments and unusually poor post-issue earnings and return performance.

Overall, we conclude that the investor's sentiment towards an IPO are an important factor in the underperformance of IPOs, if there is one.

\section{3- Performance measure methodology}

There are several alternative explanations for the aftermarket underperformance. Ritter (1991) suggests that the selection of a benchmark portfolio, the length of the period over which the performance is measured, and the sample selection criterion might explain the differences in observed performances.

One major problem with long-run performance tests is the non-standard distribution of long-run returns. Both Barber and Lyon (BL, 1997) and Kothari and Warner (KW, 1997) show that typical tests performed in the literature suffer from potential biases. KW document that the test statistics designed to detect long-run abnormal returns are positively biased, while BL document that the test statistics are generally negatively biased. Also, BL recommend the use of buy-andhold abnormal returns in tests designed to detect long -run abnormal stock returns because cumulative abnormal returns are a biased predictor of long term buy-and-hold abnormal returns (BHARs).

Lyon, Barber and Tsai (1999) confirm that the analysis of buy-and-hold abnormal returns is warranted if a researcher is interested in answering the question of whether sample firms earned abnormal stock return or not over a particular horizon of analysis. On the other hand, the cumulative abnormal return or mean monthly abnormal return over a long horizon are warranted if we want to answer the following question: do sample firms persistently earn abnormal monthly returns?

Among approaches used to measure the aftermarket performance, we retained the next two, which have recently drawn the attention of many researchers. The first approach is using the mean buy-and-hold abnormal return as an estimator of long term abnormal performance. The biggest advantage of this estimator is that it "precisely measures investor experience" and the disadvantage is that it is more sensitive to the problem of cross-sectional dependence among sample firms ${ }^{5}$. To address this problem Ikenberry, Lakonishok and Vermaelen (1995) and Lee (1997) advocate the use of the bootstrapping approach for statistical inference. However, several researchers seem sceptical using this approach. Mitchell and Stafford (2000) emphasize the problem of cross-sectional dependency and point out that the major corporate actions are not random events, and that event samples are unlikely to consist of independent observations. In

\footnotetext{
${ }^{5}$ See Brav (2000).
} 
particular, major corporate events cluster through time by industry. This leads to positive crosscorrelation of abnormal returns making test statistics severely overstated. Lyon, Barber and Tsai (1999) also find that this approach may not yield reliable statistical inference when the sample clusters on some common factors. Jegadeesh (2000) concludes that the bootstrapping approach is cumbersome to implement.

The second approach is recommended by Fama (1998) and Mitchell and Stafford (2000) and is based on calendar-time portfolios ${ }^{6}$. The major advantage of this approach is that it eliminates the problem of cross-sectional dependence among firms, since the returns on sample firms are aggregated into a single portfolio. However, this approach, unlike buy-and-hold approach, does not measure investor experience and remains sensitive to the bad-model problem, as discussed by Fama $(1998)^{7}$. Lyon and al. (1999) again argue that the calendar-time has a lower power to detect abnormal performance because it averages over the months of «hot» and «cold» event periods $^{8}$. On the other hand, Mitchell and Stafford (2000) contradict the results of Loughran and Ritter (1999), who advocate the BHAR approach and confirm that the calendar-time approach is robust to most serious statistical problems. Lyon and al. (1999, p 29) conclude «Our central message is that the analysis of long-run abnormal returns is treacherous». They suggest as a pragmatic solution to use both approaches and that's what we do here.

By comparing alternative approaches, we are able to examine the robustness of our results. The buy-and-hold strategy is easy to implement by an individual investor who makes portfolio allocation choices only infrequently. Large institutional investors will, however, be interested on measures based on quite frequent trading and rebalancing portfolios.

Loughran and Ritter (1998) point out that the choice of the weighting scheme is also important due to power considerations. Given that, should sample returns be equal or value weighted ?

Brav and al. (2000) and Lyon and al. (1999) advocate the use of the equally weighting returns if significant misevaluations are greater among small firms than among big firms. Loughran and Ritter (1998, p. 3) note that «... a traditional event study approach in which all observations are weighted equally will produce point estimates that are relevant from the point of view of a manager, investor, or researcher attempting to predict the abnormal returns associated with a random event. More generally, as Fama (1998) notes, the weighting scheme should be determined by the economic hypothesis of interest». Considering this statement, we will use equally weighting returns. Nevertheless, we also present results using value-weighting returns in section 3 to quantify investors' average wealth change subsequent to an event.

\footnotetext{
${ }^{6}$ Fama (1998) and Mitchell and Stafford (2000) argue that abnormal performance measures such as cumulative abnormal returns and time series regressions at the monthly frequency, for example, are less likely to yield spurious rejections of market efficiency relative to methodologies that calculate buy-and-hold returns by compounding single period returns. Buy-and-hold method can magnify underperformance, even if it occurs in only a single period.

${ }^{7}$ Fama (1998, p. 292) notes that «Bad-model problems are of two types. First, any asset pricing model is just a model and so does not completely describe expected returns.(...). If an event sample is titled toward small stocks, risk adjustment with the CAPM can produce spurious abnormal returns. Second, even if there were a true model, any sample period produces systematic deviations from the model's predictions».

${ }^{8}$ To control this problem, Mitchell et Stafford (2000) suggest to standardize the monthly calendar-time abnormal returns series by estimates of the portfolio standard deviation.
} 
It is clear that no winner has emerged as the optimal methodology in term of statistical properties. However, the choice of a performance measurement methodology directly determines both the size and the power of statistical test. Fama (1998) documents that if abnormal returns disappear with reasonable changes in the way they are measured, the anomaly itself is an illusion and IPOs belongs to this category. Thus, if there is an IPO anomaly, it seems to be largely restricted to tiny firms. Schwert (2001) concluded that «Does this reflect sample selection bias (so that there was never an anomaly in the first place»Or, does it reflect the actions of practioners in learning about the anomaly and trading in such away that it no longer remains profitable? ». To this question, the answer is unclear.

\section{Data and methodology}

\section{1- Sample}

Our original sample numbered 563 IPOs $^{9}$ listed in the Toronto Stock Exchange, Montreal Stock Exchange, Vancouver Stock Exchange and Alberta Stock Exchange. The primary source of data is the "Record of New Issues: Annual Report by the Financial Post Datagroup" which reports offering dates, offering prices, issue size and the name of the underwriter. Out of these 563 IPOs, 118 IPOs had to be dropped for three reasons: First of all, Datastream used to obtain the prices at the end of the first day of trading and the last day of the period does not cover the over the counter (CDN) listed companies. Second of all, return data, proceed of offering or price issue were not available. Finally, 22 IPOs were listed on the US market. This resulted in a final sample of 445 IPOs between January 1991 and December 1998.

Table 2 presents the distribution of the sample by year, both in terms of the number of offers and the gross proceeds. Further inspection of the table 2 shows that 321 of the 445 sample offers $(72,16 \%)$ occurred over 1993, 1994, 1996 and 1997. 62,84\% (\$9212,3 millions of the \$14657 millions total) of the aggregate gross proceeds in the sample were raised in these four years alone and the rest $(37,16 \%$ or $\$ 5445,6$ millions of the $\$ 14657$ millions total) was raised by the 124 IPOs that occurred over 1991, 1992, 1995 and 1998. This result is consistent with the notion of hot issues market (Ritter, 1991). Following this, we consider the years 1993, 1994, 1996 and 1997 as hot period and 1991, 1992, 1995, 1998 as cold period.

Table 3 presents the distribution of the sample by province, both in terms of the number of offers and the gross proceeds. Further inspection of table 3 shows that the sample is diversified across four provinces: The largest amount of gross proceeds occurs in Ontario (\$8148,3 millions for 170 IPOs of 445 total IPOs, 38,2\%), followed by Quebec (\$2196,3 millions for 48 IPOs of 445 total IPOs, 10,78\%), British Columbia (\$1160,3 millions for 127 IPOs of 445 total IPOs, 28,35\%) and Alberta (\$1016,3 millions for 76 IPOs of 445 total IPOs, 17,07\%).

\footnotetext{
${ }^{9}$ Units, Closed-end funds, real estate investment trusts and Junior Capital Pool companies are excluded from our sample. Unit offerings are excluded because we weren't able to separate the value of the offerings components.
} 
Table 4 presents the distribution of the sample by industry, both in terms of the number of offers and the gross proceeds. Inspection of table 4 shows that the sample also covers different industries. Oil \& gas and mining, represent 156 IPOs of 445 total IPOs (35\% of the sample). About 22\% (\$3248,65 millions of the $\$ 14657,9$ millions total) of the aggregate gross proceeds in the sample were raised by these industries.

\section{2- Methodology}

Recently, Barber and Lyon (1997), Kothari and Warner (KW, 1997), Mitchell and Stafford (2000), Loughran and Ritter (1998), Lyon and al. (1999) and Brav and al. (2000) have debated the approaches to long-run performance measurement and have examined whether a distinct performance anomaly exists or not. These authors argue that the choice of a performance measurement methodology directly determines both the size and power of statistical test.

Given this debate, we intend to use three measures to evaluate the long-run performance of initial public offerings:

a) Cumulative average adjusted returns (CAR) calculated with monthly rebalancing, where the adjusted returns are computed using a sample of control firms.

b) The buy-and-hold abnormal returns (BHAR).

c) The calendar-time abnormal returns (CTAR)

The aftermarket period includes the following 60 months where months are defined as successive 21-trading-day periods relatively to the IPO date. Thus, month 1 consists of event days 2-22, month 2 consists of event days 23-43, etc.

Monthly benchmark-adjusted returns are calculated as the monthly raw return on a stock minus the monthly benchmark return for the corresponding 21-trading-day period.

Loughran and Ritter (1995) exclude the initial returns from the calculation of the aftermarket performance. However, we think that the abnormal behaviour of IPOs is related to the misevaluation. To dissociate the error of evaluation made by investors at early hours of first trading day from the "error" made by underwriters, we suggest to also measure the aftermarket performance by the issue price ${ }^{10}$. This enables us to take a look at the performance of the IPOs acquired by mostly institutional investors, who have the chance to buy at the issue price and also to examine the performance of IPOs acquired by individual investors at the market price.

First, the benchmark-adjusted returns for stock $\mathbf{i}$ in event month $\mathbf{t}$ is defined as

$$
\mathrm{AR}_{\mathrm{it}}=\mathrm{r}_{\mathrm{it}}-\mathrm{r}_{\mathrm{mt}}
$$

where $\mathbf{r}_{\mathbf{i t}}$ is the return for firm $\mathbf{i}$ in event month $\mathbf{t}$ and $\mathbf{r}_{\mathbf{m t}}$ is the return on the benchmark during the corresponding time period.

\footnotetext{
${ }^{10}$ Thus month 1 consists of event days 1-21, month 2 consists of event days 22-42, etc.
} 
The average benchmark-adjusted return on a portfolio of $\mathbf{n}$ stocks for event month $\mathbf{t}$ is the equally-weighted arithmetic average of the benchmark-adjusted returns:

$$
\mathrm{AR}_{\mathrm{t}}=1 / \mathrm{n}_{\mathrm{t}} \sum_{i=1}^{n_{t}} A R_{i t}
$$

The cumulative benchmark-adjusted return for the aftermarket performance from event month $\mathrm{q}$ to event month $\mathrm{s}$ is the summation of the average benchmark-adjusted returns:

$$
\mathrm{CAR}_{\mathrm{qs}}=\sum_{t=q}^{s} A R_{t}
$$

The statistical significance of cumulative abnormal returns is assessed by:

$$
\mathrm{t}_{\mathrm{CAR} 1, \mathrm{t}}=\frac{C A R_{i t}}{\sigma(\mathrm{CAR}) / \sqrt{n}_{t}}
$$

Where $\sigma\left(\mathrm{CAR}_{\mathrm{it}}\right)$ is the cross-sectional sample standard deviations of abnormal returns for the sample of $n$ firms and $n_{t}$ is the number of IPOs on month $t$.

Following Barber and Lyon (1997), we prefer the use of cross-sectional standard errors because requiring pre-event return data, from which a time-series standard errors can be estimated, intensifies the new listing bias.

More specifically, the statistical test for the $\mathrm{CAR}_{1 \mathrm{t}}$ is:

$$
\mathrm{t}_{\mathrm{CAR} 1, \mathrm{t}}=\mathrm{CAR}_{1, \mathrm{t}} * \sqrt{n_{t}} / \sqrt{\left[\mathrm{t}^{*} \operatorname{var}+2 *(\mathrm{t}-1) * \operatorname{cov}\right]}
$$

Where var is the average of the cross-sectional variations over 60 months of the $\mathrm{AR}_{\mathrm{it}}$, and var is the first order auto-covariance of the $\mathrm{AR}_{\mathrm{t}}$ series.

The second measure we use is based on the calculation of the $\mathrm{T}$ holding period return ${ }^{11}$ as an alternative to the use of the cumulative benchmark-adjusted returns (no portfolio rebalancing is assumed in these calculations), defined as:

$$
\mathrm{R}_{\mathrm{iT}}=\prod_{t=1}^{T}\left(1+r_{i t}\right)
$$

Where $\mathbf{T}$ is number of months and $\mathbf{r}_{\mathbf{i t}}$ is the raw return on firm $\mathbf{i}$ in event $\mathbf{t}$. This measures the total return from a buy and hold strategy where a stock is purchased at the first closing market price after going public and held until the earlier of its $\mathbf{T}$ anniversary.

The holding period return on the benchmark during the corresponding period for firm $\mathbf{i}, \mathbf{R}_{\mathbf{m} \mathbf{T}}$ is also similarly calculated.

The mean buy-and-hold return is calculated as

\footnotetext{
${ }^{11}$ Roll(1983, p. 377) point out that buy-and- hold method «(...) gives an unbiased estimate of the holding period return on a realistic portfolio ».
} 


$$
\mathrm{R}_{\mathrm{T}}=1 / \mathrm{n}\left[\sum_{i=1}^{N} R_{i T}\right]
$$

The buy-and-hold abnormal return (BHAR) is defined as follows:

$$
\mathrm{BHAR}_{\mathrm{i}, \mathrm{T}}=\left[\prod_{t=1}^{T}\left(1+r_{i t}\right)-1\right]-\left[\prod_{t=1}^{T}\left(1+r_{m t}\right)-1\right]
$$

Where $r_{m t}$ is the return on the benchmark during the corresponding time period.

The mean buy-and-hold abnormal returns for a period $t$ is defined as:

$$
\mathrm{BHAR}_{\mathrm{t}}=\sum_{\mathrm{i}=1}^{\mathrm{nt}} \mathrm{X}_{\mathrm{it}} \mathrm{BHAR}_{\mathrm{it}}
$$

The weight $\mathbf{x}_{\mathbf{i t}}$ is $1 / \mathbf{n}_{\mathbf{t}}$ when abnormal returns are equally-weighted and $\mathbf{M V}_{\mathbf{i t}} / \sum_{i=1}^{n t} M V_{i t}$ when abnormal returns are value weighted, $\mathbf{M V}$ is the market value and $\mathbf{n}_{\mathbf{t}}$ is the number of companies during the period.

To test the null hypothesis of zero mean buy-and-hold return, we preferred the skewnessadjusted t statistic advocated by Neyman and Pearson (1928) and recently used by Lyon et al (1999). The t-statistic is defined as:

$$
\mathrm{t}=\sqrt{\mathrm{n}} \times\left(\mathrm{S}+\frac{1}{3} \hat{\gamma} \mathrm{S}^{2}+\frac{1}{6 \mathrm{n}} \hat{\gamma}\right)
$$

where $S=\frac{\text { Mean }(\text { BHAR })_{t}}{\sigma(\text { BHAR })_{t}} ; t=12,24,36,48$ et 60 months;

$\hat{\gamma}$ is an estimate of the coefficient of skewness.

The third measure we use is based on the calendar-time portfolio methods, which eliminate the problem of cross-sectional dependence among sample firms.

We assume that the event period is five years. For each calendar month, we calculate the abnormal return $\left(\mathrm{AR}_{\mathrm{it}}\right)$ :

$$
\mathrm{AR}_{\mathrm{it}}=\mathrm{r}_{\mathrm{it}}-\mathrm{r}_{\mathrm{mt}}
$$

where $r_{i t}$ is the return for firm $i$ in event month $t$ and $r_{m t}$ is the return on the benchmark during the corresponding time period.

In each calendar month $t$, we calculate a mean return $\left(\mathrm{MAR}_{\mathrm{t}}\right)$ across firms in the portfolio :

$$
\mathrm{MAR}_{\mathrm{t}}=\sum_{i=1}^{n t} x_{i t} A R_{i t}
$$


The weight $\mathbf{x}_{\mathbf{i t}}$ is $1 / \mathbf{n}_{\mathbf{t}}$ when abnormal returns are equally-weighted and $\mathbf{M} \mathbf{V}_{\mathbf{i t}} / \sum_{i=1}^{n t} M V_{i t}$ when abnormal returns are value weighted and $\mathbf{n}_{\mathbf{t}}$ is the number of firms in the portfolio in month $\mathbf{t}$. This number in calendar-time portfolio varies from month to month. If in a particular calendar month there are no firms in the portfolio, then that month is dropped.

Then, we calculate a grand mean monthly abnormal returns (MMAR) using $\mathbf{M A R} \mathbf{R}_{\mathbf{t}}$ :

$$
\text { MMAR }=1 / \mathrm{T} \times \sum_{i=1}^{T} \mathrm{MAR}_{\mathrm{t}}
$$

where $\mathrm{T}$ are the total number of calendar months.

To test the null hypothesis of zero mean monthly abnormal returns, a t statistic is calculated using the time-series standard deviation of the mean monthly standardized abnormal returns :

$$
\mathrm{t}(\mathrm{MMAR})=\text { MMAR } / \sigma\left(\text { MAR }(\text { standardized })_{\mathrm{t}}\right) \times \sqrt{\mathrm{T}}
$$

The monthly MAR are standardized by estimates of the portfolio standard deviation, for two reasons (Mitchell and Stafford, 2000). First, we control for heteroskedasticity and second, we give more weight to periods of heavy event activity than periods of low event activity (the portfolio residual variance is decreasing in portfolio size, all things equal).

Barber et Lyon (1996) present three ways to control the calculation of excess returns: the reference portfolio, the three factor model of Fama and French (1993) and the control firms. They document however, in comparing control firm approach to the reference portfolio that the control firm approach eliminates the new listing bias (since both the sample and control firm must be listed in the identified event month), the rebalancing bias (since both the sample and control firm returns are calculated without rebalancing), and the skewness problem (since the sample and control firm are equally likely to experience large positive returns).

On the other hand, in comparing the use of the reference portfolio to the use of Fama-French model to control the excess returns, Lyon and al. (1999) show that the latter assumes implicit linearity in the constructed market, size, and book-to-market factors, which is not verified at least during their period of analysis (1973-1994). They sustained that the three factor model assumes there is no interaction between the three factors. Loughran (1997) shows however that the relation between book-to-market ratio and returns is most pronounced for small firms.

According to these studies, we use the control firms approach. However, the measurement bias remains when the control firm approach and the cumulative abnormal returns are used to detect long-run abnormal stock returns.

We choose a non-issuing matching firm for each issuing firm. To choose a matching firm, on each December 31 all common stocks listed on the Canadian stock exchanges that have not issued $^{12}$ stock within the last five years are ranked by their market capitalization. The firm whose

\footnotetext{
${ }^{12}$ Loughran and Ritter (2000) point out that "a test biased towards explanatory power and no abnormal returns if it uses a benchmark that is contaminated with many of the firms that are the subject of the test".
} 
market capitalization is between 80 and $120 \%$ of that of the issuing firm is then chosen as its matching firm. We also considered, but have abandoned, the use of a control firm of similar size and book-to-market ratio ${ }^{13}$ since this approach considerably reduces the number of firms in our sample $^{14}$.

If the control firm is delisted before the end of the year, we fill the missing return with the matching control firm return, which respects the same filter (a market capitalization between 80 et $120 \%$ ). If a chosen matching firm subsequently issues stock, we treat it as if it is delisted on its offering date.

We choose not to consider matching by industry because an industry can time its offers to take advantage of industry-wide misevaluations. Controlling for industry effects will reduce the ability to identify abnormal performance (Loughran and Ritter, 1995).

Finally, in calculating the BHARs for individual firms, if the sample firm is delisted, we fill in the missing return with the control firm return. If the sample firm is delisted before the end of the five years period, we do not rebalance the portfolio, so each BHAR is a true buy-and-hold return.

\section{Long-term performance results}

\section{1- Long-term performance measured from the issue price}

Figure 1 provides evidence on relative performance with respect to our sample of control firms. Table 5 provides a summary of results of cumulative abnormal returns (CARs), over 60-month for 445 Canadian IPOs between January 1991 and December 1998. It is clear from these results that IPO underperformed by approximately $12,35 \%$ as measured by EW CAR over the first 12 months of listing in comparison to the non-issuing matching firms, and this underperformance is considered significant. From this point on, the underperformance, as well as its significance, dropped. At 36 months, the CAR was $-6,15 \%$ (t-statistic =-0,47). At 60 months, the CAR was 20,65\% (t-statistic $=-0,84$ ). The VW CAR are smaller in magnitude than EW CAR (see table 7). At 36 months, the VW CAR was still positive 0,02\% (t-statistic = -1,29). At 60 months, the VW CAR was $-11,02 \%$ (t-statistic $=-1,67$ ). Clearly, those IPOs that continued to be listed for a long period, provided returns much smaller compared to other companies on the stock market, after 20 months of performance or "honeymoon" (on EW basis) and 37 months (on VW basis).

Table 7 provides the summary of the results obtained using the BHAR as a second measure of aftermarket performance. Clearly, on EW basis, a zero initial investment in the new issues would have resulted in a loss for the investor of $6,58 \%$ by the end of 36 months and of $24,65 \%$ by the end of 60 months in the post-IPO period. On VW basis, the underperformance is smaller. A zero initial investment in the new issues would have resulted in a loss for the investor of $2,72 \%$ by the end of 36 months and 15,16\% by the end of 60 months. The underperformances obtained from BHAR analysis are larger than those obtained from CAR analysis. This confirms the result of

\footnotetext{
${ }^{13}$ See Brav and Gompers (1997 and 1999).

${ }^{14}$ For the majority of control firms, it wasn't possible to have the book value to determine the book-to-market ratio.
} 
Barber and Lyon (1997) who have shown that CAR gives positively biased test statistics and BHAR gives negatively biased test statistics. Figures 2, 3, 5 and 6 confirm these observations.

The results from the CTAR analysis show that on EW basis, the mean monthly calendar-time abnormal return is $-0,34 \%$ ( $\mathrm{t}$-statistic $=-0,66$ ) which correspond to $-12,39 \%$ underperformance

for the three years after the issue or to $-20,65 \%$ underperformance for the five years after the issue. On VW basis, the mean monthly calendar-time abnormal return is $-0,1837 \%$ ( $\mathrm{t}$-statistic $=$ $-0,51$ ) which correspond to $-6,61 \%$ underperformance for the three years after the issue or to $11,02 \%$ underperformance for the five years after the issue.

These results are based on the fact that we include initial returns to measure the aftermarket performance. In the next section, the aftermarket performances are measured from the first closing market price.

\section{2- Long-term performance measured from the first closing market price}

Figure 4 provides evidence on relative performance with respect to our sample of control firms while table 6 provides a summary of results of cumulative abnormal returns (CARs), over 60month for 445 Canadian IPOs between January 1991 and December 1998. It is clear from these results that IPO underperformed by approximately 10,79\% as measured by EW CAR over the first 12 months of listing in comparison to the non-issuing matching firms, and this underperformance was significant. From this point on, the underperformance, as well as its significance, declined. At 36 months, the CAR was $-16,85 \%$ (t-statistic $=-1,28$ ). At 60 months, the CAR was $-25,68 \%$ (t-statistic $=-1,04$ ). The VW CAR are smaller in magnitude than EW CAR. At 36 months, the VW CAR was $-9,39 \%$ (t-statistic = -2,45). At 60 months, the VW CAR was $-19,23 \%(\mathrm{t}$-statistic $=-2,68)$.

The magnitude of underperformance in the Canadian IPO market is found to be different than the results reported by Jog (1997). In particular, our cumulative abnormal residual for Canadian sample by month 36 is $-9,65 \%$ compared to $-41.02 \%$ for Jog (1997). This difference may be explained by the fact that Jog considered only companies listed on the Toronto Stock Exchange (TSE), which limits the introduction to the larger firms. However, in this context, we expect to see smaller underperformance for the TSE IPOs. The most likely explanation for the differences in results may be the selection of a benchmark portfolio. Jog used two benchmarks : the TSE 300 Composite Index and the value-weighted index of TSE-Western Database which gives more weight to larger stocks.

Table 7 provides the summary of results using the BHAR as a second measure of aftermarket performance. Clearly, on EW basis, a zero initial investment in the new issues would have resulted in a loss for the investor of $19,96 \%$ by the end of 36 months and 26,5\% by the end of 60 months in the post-IPO period. On VW basis, the underperformance is less important. A zero initial investment in the new issues would have resulted in an investor's loss of $12,32 \%$ by the end of 36 months and $20,61 \%$ by the end of 60 months. Brav and al. (2000) confirm these results using a sample of US IPOs and different benchmarks. 
The results from the CTAR analysis show that on EW basis, the mean monthly calendar-time abnormal return is $-0,42 \%$ ( $\mathrm{t}$-statistic $=-2,00$ ) which corresponds to $-15,5 \%$ underperformance for the three years after the issue or to $-25,6 \%$ underperformance for the five years after the issue. On VW basis, the mean monthly calendar-time abnormal return is $-0,32 \%$ ( t-statistic = 1,38 ) which corresponds to $-11,53 \%$ underperformance for the three years after the issue or to $19,22 \%$ underperformance for the five years after the issue.

The main conclusion from this section is that the aftermarket performance measured from the issue price is smaller than the one measured from the first closing market price. This difference is mainly explained by the relatively high underpricing of Canadian IPOs. Investors who are not willing to buy stocks at issue prices, mostly individual investors, don't benefit from the high initial returns and they earn substantial losses, starting from the second month after the issue. Nevertheless, the institutional investors who generally buy stocks at issue prices earn profits up until the $20^{\text {th }}$ month after the issue. Figures 7, 8, 9 and 10 confirm this observation. Our results also confirm the fact that the choice of a performance measurement methodology directly determines both the size and power of statistical test. For the overall period, it is obvious that the portfolio of IPOs underperform the sample of the matching firms for 60 months following the IPO listing. Undoubtedly, Canadian IPOs aren't a good long-term investment. But why do investors still buy newly issued stocks ? We still have to find a plausible explanation for the underperformance of IPOs in Canada and to analyse the relationship between the aftermarket performance and sample characteristics.

\section{2- Cross-sectional patterns}

We now turn to the cross-sectional analysis of the long-run performance of the IPOs. Table 8 shows BHARs by proceeds, initial return, and industry sectors. While both issues with gross proceeds smaller than $\$ 10$ million and those with $\$ 10$ million and more, underperform in the aftermarket, the first ones perform worse than the latter ones on the 60 months. This corroborates the hypothesis that the ex-ante uncertainty is related positively with the underperformance.

Other results in table 8 suggest that overpriced stocks perform better than underpriced stocks. This confirms the existing U.S evidence, which indicates that underpriced stocks show a more negative long-term performance. This result is mildly supportive of the overreaction or fads hypothesis. DeBondt and Thaler $(1985,1987)$ have also presented evidence that, at least for lowcapitalization stocks, there is a negative relation between past and subsequent abnormal returns on individual securities using holding periods of a year or more.

When the sample is segmented by industry, we notice that the long-run performance of IPOs varies widely in different industries. For example, financial IPOs outperform at 12, 24, 36, 48 and 60 months. Mining IPOs underperform at 12, 24, 36, 48 and 60 months. This underperformance may be explained by the high initial returns for this sector $(35,71 \%)$. Oil and gas IPOs show the same pattern as mining IPOs but the underperformance at 60 months is not statistically significant. We also observe that oil and gaz perform worse than those of other sectors (-37,94\% at 60 months). Also, Ritter (1991) found that oil and gas IPOs in the U.S. had 
high initial returns but very poor aftermarket performance. He reports that American financial company IPOs had better three-year stock return performance than those in other sectors.

Technology IPOs also underperform over the same period. Technology IPOs had among the highest aftermarket underperformance.

Communications and media and merchandising IPOs are overpriced and exhibit less dramatic underperformance than other sectors. At 60 months, communications and media IPOs outperform the matching control firms.

Overall, the 3-year underperformance of IPOs is present in all but one of the 10 industry groupings. Also, the 5-year underperformance of IPOs is present in all but two of the 10 industry groupings.

We also segmented the sample in two periods in terms of number and volume of issues. 1993, 1994, 1996 and 1997 present the hot period and 1991, 1992, 1995 and 1998 present the cold period. This segmentation shows that the underperformance of Canadian IPOs is not a general phenomena. At 36 months, the BHAR is $-18,06 \%$ for hot issues and $-10,41 \%$ for cold issues. At 60 months, the BHAR is $-39,08 \%$ for hot issues and $--4,6 \%$ for cold issues. ). The t-value on the difference in average initial return between hot and cold IPOs is significant at $1 \%$ level.

In table 9, firms are categorized by their year of issue. The negative relation between annual volume and aftermarket performance, which is evident in table 11, fits with the fact that firms choose to go public when investors are willing to pay high multiples (prices-earnings or marketto-book) reflecting the optimistic assessments of the net present value of growth opportunities. Ritter (1991) documents that "investors are periodically overoptimistic about the earnings potential of young growth companies". He also finds that "If there are periods when investors are especially optimistic about the growth potential of companies going public, the large cycles in volume may represent a response by firms attempting to time their IPOs to take advantage of these swings in investors' sentiment ". This explanation is consistent with the window of opportunity hypothesis.

The subsequent negative aftermarket performance observed is then due to the loss of optimism of investors, who recognize that the earnings are not maintaining their momentum. All things equal, the greater the disappointing realizations of the net cash flows are, the larger the ultimate correction price correction will be. Teoh and al. (1998) observe that issuers of IPOs can report earnings in excess of cash flows by taking positive accruals. They also provide the evidence that issuers with unusually high accruals in the IPO year experienced poor stock return performance in the three years thereafter.

Overall, it is apparent that IPOs underperform a sample matching firms with the same market capitalization. We can also conclude that the underperformance varies across industries and the period of issue. The high initial return of Canadian IPOs may also explain the aftermarket underperformance. 


\section{3- Results of multiple regressions}

In this section, five ordinary least square regressions were performed. BHARs are estimated after $12,24,36,48$ and 60 months respectively in order to assess the relationship between BHARs and issue-specific factors in multivariate context. The regression model has the following form:

$$
\begin{gathered}
\text { BHAR }_{1, \mathrm{~s}}= \\
\alpha_{0}+\alpha_{1} \text { MINING }_{i}+\alpha_{2} \mathrm{O \& G}_{\mathrm{i}}+\alpha_{3} \mathrm{~T}_{\mathrm{i}}+\alpha_{4} \mathrm{UND}_{\mathrm{i}}+\alpha_{5} \log \text { (Proceeds) }{ }_{\mathrm{i}}+\alpha_{5} \text { HOT/COLD }+\varepsilon_{\text {is }}
\end{gathered}
$$

Where $\mathbf{s}$ takes on a value of $12,24,36,48$ or 60, MINING $_{\mathbf{i}}$ takes a value of 1 for mining issues and zero otherwise, $\mathbf{O \&} \mathbf{G}_{\mathbf{i}}$ takes a value of 1 for oil and gas issues and zero otherwise, $\mathbf{T}$ takes a value of 1 for technology issues and zero otherwise, $\mathbf{U N D}_{\mathbf{i}}$ is the underpricing in stock $\mathbf{i}$, HOT/COLD takes a value of 1 for hot issues and 0 otherwise and Log denotes the natural logarithm. The proceed of the issue is used as a proxy for ex-ante uncertainty.

The results of multiple regression tests based on t-statistics on $\hat{\alpha}_{i}$ are provided in table 10. At first glance, it becomes evident that no statistically significant relationship which is stable in time emerges between the underpricing and BHARs or between the proceeds and BHARs at 36 and 48 months. According to Shiller (1990), the long-run performance of IPOs should be negatively related to the short-run underpricing. While according to Miller (1977), IPOs long-run return should be negatively related with its ex-ante uncertainty (i.e., positive relationship between longrun performance and Log (proceeds) because the ex-ante uncertainty is inversely related to a firm's size). Our results suggest that neither investor's overreactions hypothesis nor divergence of opinions hypothesis explain the long-run performance of Canadian IPOs.

The first significant negative relationship between BHARs and MINING can be observed for BHARs at 24, 36 and 48 months. This confirms the fact that the mining IPOs underperform the matching control firms. According to the five regressions, O\&G has a negative coefficient reflecting the poor performance of the oil and gas IPOs. This relationship is significant only for the 48 months and the 60 months. On the other hand, the relationship between the technology variable and BHARs is negative and significant for the 24 months and the 36 months. In the previous section, we suggested that the high underpricing for these sectors may explain the long term underperformance. However, we find a positive relationship between BHARs and UND when BHAR is estimated at the 24, 36, 48 and 60 month, which allow us to suggest that the underperformance washes out the initial high returns earned on the first trading day and that the divergence of opinion hypothesis doesn't explain the poor aftermarket performance of IPOs in Canada.

A positive relationship between BHARs and proceed variable can be observed at 12, 24 36, 48 and 60 months. However, this relationship is only significant for the 12 months and the 24 months. Theses results confirm slightly the intuition that the ex-ante uncertainty may explain the first two years performance for IPOs ${ }^{15}$. Moreover, a significant negative relationship between

\footnotetext{
${ }^{15}$ Hong et Stein (1999) point out that «Both short-run continuation and long-run reversals should be more pronounced in those (small, low-analyst-coverge) stocks where information diffuses more slowly».
} 
BHARs and HOT/COLD can be observed for BHARs at 12, 24, 36, 48 and 60 months. This finding confirms the window of opportunity hypothesis.

Overall, these results clearly indicate that the firms going public during hot issues market underperform in the long-run. This is consistent with the windows of opportunity hypothesis (Ritter (1991) and Loughran and Ritter (1995)). We also conclude that the underperformance varies across industries.

\section{Conclusion}

The paper examines the stock market performance of Canadian initial public offerings during the period 1991 to 1998 . The initial returns on the first trading day have averaged a 20,57\%. The high initial prices on the first day of listing may be due to the myopia of investors, who are unable to fully understand the extent to which IPO firm engage in earnings management (Teoh et al. 1998). To examine whether the choice of a performance measurement methodology directly determines both the size and power of statistical test, as documented in previous studies (Mitchell and Stafford, 2000; Loughran and Ritter, 2000; and Brav, Geczy and Gompers, 2000), we used different approaches.

Using cumulative abnormal returns as an abnormal performance measure, we find that the Canadian IPOs underperform significantly in comparison to the sample of seasoned firms with the same market capitalization. The underperformances on 36 and 60 months are statistically significant (on value weighted basis). Moreover, using the buy-and hold returns as an alternative measurement for long-run performance, we found that investors who buy immediately after listing and hold shares for five years will make a 24,66\% (on equally weighted basis) and $15,16 \%$ (on value weighted basis) losses on an investment in one of the control firms. Using the calendar-time returns method, we found that the 5 years underperformance of the IPOs is $-25,6 \%$ (on equally weighted basis) and $-19,22 \%$ (on value weighted basis).

When the sample is segmented by industry, we noticed that the long-run performance of IPOs varies widely in different industries. Mining, oil \& gas and technology issues perform worse than those of other sectors.

We have entertained a number of possible explanations for the poor subsequent performance of issuing firms. Despite the fact that, the fads or investor's overreaction and divergence of opinions hypotheses do not apply in explaining the aftermarket performance of Canadian IPOs, our evidence is consistent with a market where firms take advantage of windows of opportunity by issuing equity during hot issues markets. Some other studies have confirmed the window of opportunity hypothesis as a viable explanation of the aftermarket underperformance of IPOs (Ritter 1991, Loughran and Ritter 1995).

Among those firms that do go public, investors must be able to fully distinguish the high-value firms from low-value firms, otherwise wealth transfers will result. On the other hand, issuers of IPOs or the high-value firms have incentives to differentiate themselves, in order to raise capital on more favourable terms. 


\section{References}

Affleck-Graves, J., Hegde S., Miller, E., 1996, «Conditional price trends in the aftermarket for initial public offerings », Financial Management 25, p. 25-40.

Aggarwal, R., Leal, R., Hernandez, F., 1993, « The aftermarket performance of initial public offerings in Latin America », Financial Management 22, p. 42-53.

Aggarwal, R., Rivoli, P., 1990, «Fads in the initial public offering market?», Financial Management 19, p. 45-57.

Allen, F., Faulhaber, G.R., 1989, «Signalling by underpricing in the IPO market», Journal of financial Economics 23, p. 303-323.

Aussenegg, W., 1997, «Short and long-run performance of initial public offerings in the Austrian stock market », Unpublished Vienna University of Technology working paper.

Barber, B., Lyon, J., 1996, «Detecting abnormal operating performance : The empirical power and specification of test statistics », Journal of Finance 41, p. 359-399.

Barber, B., Lyon, J., 1997, « Detecting long-run abnormal stock returns: the empirical power and specification of test statistics », Journal of Financial Economics 43, p. 341-372.

Barber, B., Lyon, J., 1998, «How can long-run abnormal stock returns be both positively and negatively biased? », SSRN working Paper.

Barberis, N., Shleifer, A., Vishny, R., 1998, « A model of investor sentiment », Journal of Financial Economics 49, p. 307-343.

Biais, B., Faugeron, A., 2000, « IPO auctions :English, Dutch, ..., French and Internet», University of Toulouse working paper.

Brav, A., 2000, «Inferences in long-horizon event studies: A Bayesian approach with applications to initial public offerings», Journal of Finance 55, p. 1979-2016.

Brav, A., Geczy, C., Gompers, P., 2000, «Is the abnormal return following equity issuance anomalous? » Journal of Financial Economics 56, p. 209-249.

Brav, A., Gompers, P., 1997, « Myth or reality? The long-run underperformance of initial public offerings: Evidence from venture and non venture capital-backed companies », Journal of Finance 52, p. 1791-1821.

Brown, S., Warner, J., 1980, «Measuring security price performance », Journal of Finance Economics 8(3), p. 205-258.

Brown, S., Warner, J., 1985, «Using daily stock returns: the case of event studies », Journal of Finance Economics 14(3), p. 491-495.

Buser, S., Chan, K., 1987, «NASDAQ/NMS Qualification stand, Ohio registration experience and the price performance of initial public offerings », Ohio Department of Commerce and national Association of Securities Dealers Inc., Columbus. 
Cai, J., Wei, K., 1997, «The investment and operating performance of Japanese IPO», PacificBasin Finance Journal 5, p. 389-417.

Camerer, C., 1989, «Bubbles and fads in asset prices: a review of theory and evidence», Journal of Economic Surveys, p. 3-41.

Chen, A., Pan. K., 1998, « An answer to the long-run performance puzzle of IPOs in Taiwan: An application of the Fama-French model », National Sun Yat-Sen University working paper.

Daniel, K., Titman, S., 1997, "Evidence on the characteristics of cross-sectional variation in stock returns », Journal of Finance 52(1), p. 1-33.

Daniel, K., Hirshleifer, D., Subrahmanyam, A., 1998, « Investor psychology and security market under- and overreactions », Journal of Finance 53, p. 1839-1885.

Davis, J., Fama, E., French, K., 2000, « Covariances and average returns: 1929-1997 », Journal of Finance 55(1), p. 389-406.

De Bondt, W., Thaler, R., 1985, «Does the stock market overreact? », Journal of Finance 40, p. 793-808.

Eckbo, B, Norli, O., 2000, «Leverage, liquidity and long-run IPO returns », SSRN working paper.

Fama, E., 1998, «Market efficiency, long-term returns, and behavioural finance » Journal of Financial Economics 49, p. 283-306.

Fama, E., French, K., 1993, «Common risk factors in returns on stocks and bonds » Journal of Financial Economics 33, p. 3-56.

Field, L., 1995, «Is institutional investment in initial public offerings related to long-run performance of these firms? », Pennsylvania State University working paper.

Finn, F, Higham, R., 1988, "The performance of unseasoned new equity-issues-cum-stock exchange listings in Australia», Journal of Banking and Finance 12, p. 333-351.

Firth, M., 1997, «An analysis of the stock market performance of new issues in New Zealand», Pacific-Basin Finance Journal 5, p. 63-85.

Friedlan J., Maynes, E. et Verma, S., 1994, « The Long Run Performance of Canadian Initial Public Offerings », Schulisch School of Business, York University working paper.

Goergen, M., 1998, «Insider retention and long-run performance in German and UK IPOs », School of management, UMIST working paper.

Holhausen, R., Larcker, D., 1996, «The financial performance of reverse leveraged buyouts », Journal of Financial Economics 42, p. 293-332.

Hong, H., Stein, J., 1999, «A unified theory of under-reaction, momentum trading and overreaction in asset markets», Journal of Finance 54, p. 2143-2184.

Ibbotson, R., 1975, «Price performance of common stock new issues », Journal of Financial Economics 2, p. 235-272. 
Ibbotson, R., 1975, «Price performance of common stock new issues », Journal of Financial Economics 2, p. 235-272.

Ikenberry, D., Lakonishock, J., Vermaelen, T., 1995, « Market under-reaction to open market share repurchases », Journal of Financial Economics 39, p. 181-208.

Jegadeesh, N., 2000, «Long-term performance of seasoned equity offerings: Benchmark errors and biases in expectations », Financial Management, p. 5-30.

Jensen, M., Meckling, W., 1976, «Theory of the firm: Managerial behaviour, agency costs and ownership structure», Journal of Financial Economics 3, p. 306-360.

Jog, V., 1997, «The climate for Canadian initial public offerings », Financing Growth in Canada, ed. P. Halpern, University of Calgary press, p. 357-401.

Jog, V., McConnomy, B., 1999, «Voluntary disclosure of management earnings forecasts in IPOs and the impact on underpricing and post-issue return performance», SSRN working paper.

Keloharju, M., 1993, «The winner's curse, legal liability, and the long-run price performance of initial public offerings in the Finland », Journal of Financial Economics 34, p. 251-277.

Kim, J., Krinsky, I., Lee, J., 1995, « The aftermarket performance of initial public offerings in Korea», Pacific-Basin Finance Journal 3, p. 429-448.

Kim, M., Ritter, J., 1999, « Valuing IPOs », Journal of Financial Economics 53:3, p. 409-437.

Kothari, S., Warner, J., 1997, «Measuring long-horizon security price performance », Journal of Financial Economics 43, p. 301-339.

Krigman, L., Shaw, W., Womack, K., 1997, «The persistence of IPO Mispricing and the predictive power of flipping », unpublished Dartmouth College working paper.

Kunz, R., Aggarwal, R., 1994, «Explaining the underpricing of initial public offerings: Evidence from Switzerland », Journal of Banking and Finance 18, p. 705-723.

Lee, I., 1997, « Do managers knowingly sell overvalued equity ?», Journal of Finance 52(4), p. 1439-1466.

Lee, P., Taylor. S., Walter, T., 1996, « Australian IPO underpricing in the short and long run », Journal of Banking and Finance 20, p. 1189-1210.

Levis, M., 1993, «The long-run performance of initial public offerings: The UK experience 1980-1988 », Financial Management 22, 28-41.

Ljungqvist, A.P., 1997, «Pricing initial public offerings : Further evidence from Germany », European Economic Review 41, p. 1309-1320.

Loughran, T., 1995, «Book-to-market across firm size, exchange, and seasonality: Is there an effect ?», Journal of Financial and Quantitative Analysis 32, p. 249-268.

Loughran, T., Ritter, J., 1995, «The new issues puzzle », Journal of Finance 50, p. 23-51. 
Loughran, T., Ritter, J., 1998, «Uniformly least powerful tests of market efficiency », Unpublished manuscript, University of Florida.

Loughran, T., Ritter, J., Rydqvist, K., 1994, «Initial public offerings: international insights », Pacific-Basin Finance Journal 2, p. 165-199.

Lowry M., Schwert, G., 2000, «IPO market cycles: an explanatory investigation », SSRN working paper.

Lowry M., Schwert, G., 2001, «Biases in the IPO pricing process », NBER working paper.

Lyon, J., Barber, B., Tsai, C., 1999, «Improved methods for tests of long-run abnormal stock returns », Journal of Finance 54, p. 165-201.

MacKinlay, A., 1997, «Event studies in economics and finance », Journal of Economic Literature, p. 13-39.

McGuinness, P., 1992, «An examination of the underpricing of initial public offerings in Hong Kong », Journal of Business Finance and Accounting 19, p. 165-186.

Mikkelson, W., Partch, M., Shah, K., 1997, «Ownership and operating performance of companies that go public », Journal of Financial Economics 44, p. 281-307.

Miller, E., 1977, «Risk, uncertainty and divergence of opinion», Journal of Finance, p. 1151-1168.

Miller, E., 2000, «Long run underperformance of initial public offerings: An explanation », University of New Orleans working paper.

Mitchell, M., Stafford, E., 2000, «Managerial decisions and long-term stock price performance », Journal of Business 73, p. 287-329.

Neyman, J., Pearson, E., 1928, « On the use and interpretation of certain test criteria for purposes of statistical inference, part I », Biometrica 20A, p. 175-240.

Paudyal, K., Saadouni, B., Briston, R., 1998, «Privatisation initial public offerings in Malaysia: Initial premium and long-term performance», Pacific-Basin Finance Journal 6, p. 427451.

Rajan, R., Servaes, H., 1997, «Analyst following of initial public offerings », Journal of Finance 52, p. 507-529.

Ritter, J., 1998, « Initial public offerings», Contemporary Finance Digest, Vol. 2, No. 1, p. 5-30.

Ritter, J., 1984, « The hot issue market of $1980 »$, Journal of Business 32, p. 215-240.

Ritter, J., 1991, «The long-run performance of initial public offerings », Journal of Finance 46, p. 3-27.

Ritter, J., 1987, « The costs of going public », Journal of Financial Economics 19, p. 269-281. 
Ritter, J., 2001, «Investment banking and securities issuance », chapter 9 of North-Holland Handbook of the Economics of Finance, ed. George Constantinides, Milton Harris et Rene Stulz, (forthcoming 2002).

Roll, R., 1983, «On computing mean returns and small firm premium », Journal of Financial Economics 12, p. 371-386.

Rydqvist, K., Häogholm, K., 1995, «Going public in the 1980s: evidence from Sweden », European Financial Management 1, p. 287-315.

Shiller, R., 1981, «Do stock prices move too much to b justified by subsequent changes in dividend?», American Economics Review, p. 421-436.

Shiller, R., 1990, « Speculative prices and popular models», Journal of Economic perspectives 4, p. 55-65.

Schwert, G., 2001, «Anomalies and market efficiency», chapter 17 of North-Holland Handbook of the Economics of Finance, ed. George Constantinides, Milton Harris et Rene Stulz, (forthcoming 2002).

Teoh, S., Welch, I., Wong, T., 1998, «Earnings management and the post-issue underperformance in seasoned equity offerings », Journal of Financial Economics 50, p. 63-99.

Teoh, S., Welch, I., Wong, T., 1998, «Earnings management and the long-run market performance of initial public offerings », Journal of Finance 53, p. 1935-1974.

Uhler, H., 1989, « Going public in the F.R.G », R. Guimaraes, B. Kingsman and S. Taylor, eds., A reappraisal of the efficiency of financial markets (Springer-Verlag, Berlin), p. 369-393.

Welch, I., 1989, «Seasoned offerings, imitation costs and the underpricing of initial public offerings », Journal of Finance 44, p. 421-449. 
Figure 1 Cumulative abnormal returns (CAR). The sample consists of 445 Canadian IPOs by firms subsequently listed on the Toronto Stock Exchange, the Montreal Exchange, the Vancouver Exchange and the Alberta Exchange, from January 1991 through December 1998. The aftermarket performance is measured from the issue price. CAR VW is the weighted value cumulative abnormal returns and the CAR EW is the equally weighted cumulative abnormal returns.

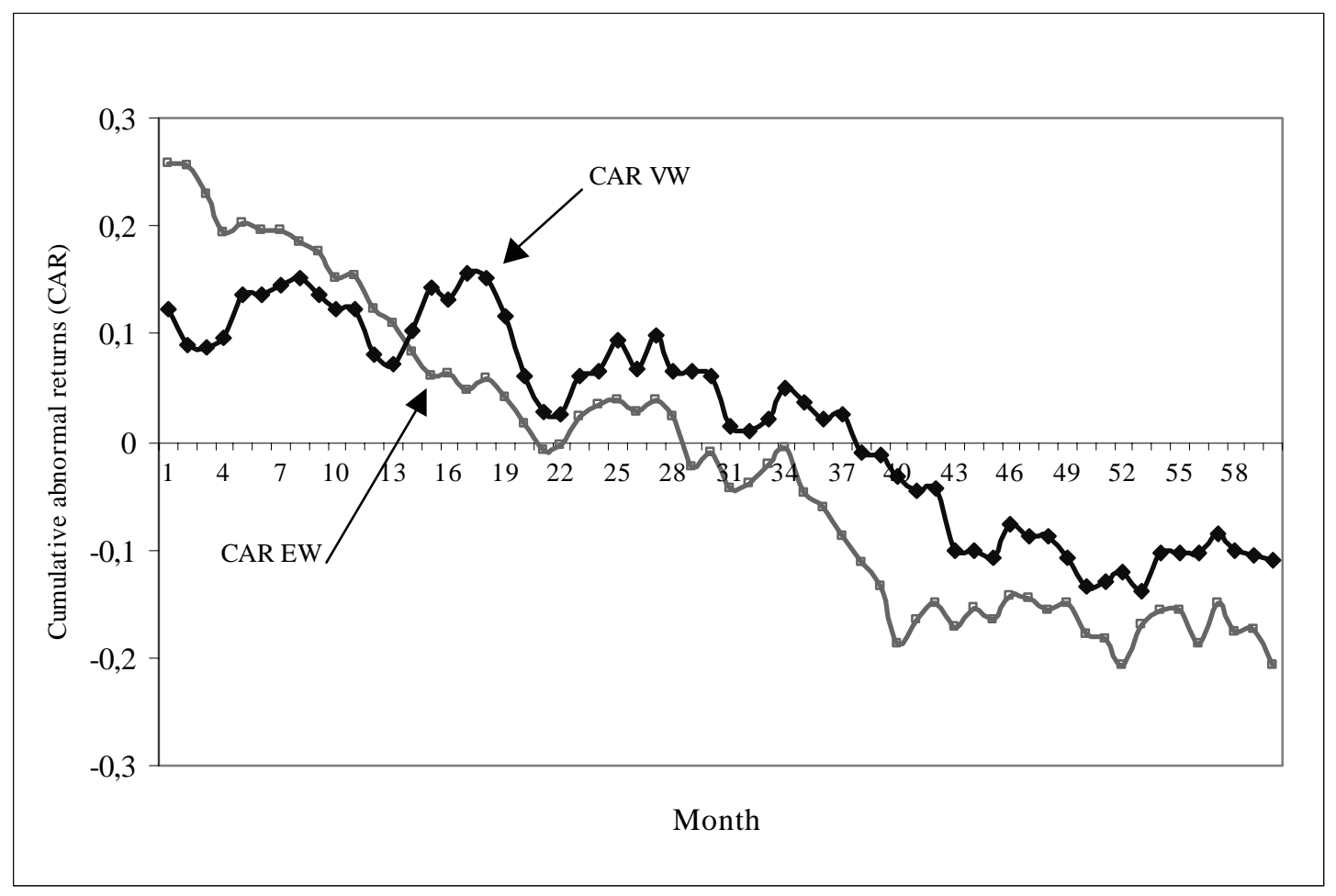

Figure 2 Cumulative abnormal returns (CAR) and buy-and-hold abnormal returns(BHAR). The sample consists of 445 Canadian IPOs by firms subsequently listed on the Toronto Stock Exchange, the Montreal Exchange, the Vancouver Exchange and the Alberta Exchange, from January 1991 through December 1998. The aftermarket performance is measured from the issue price on equally weighted base.

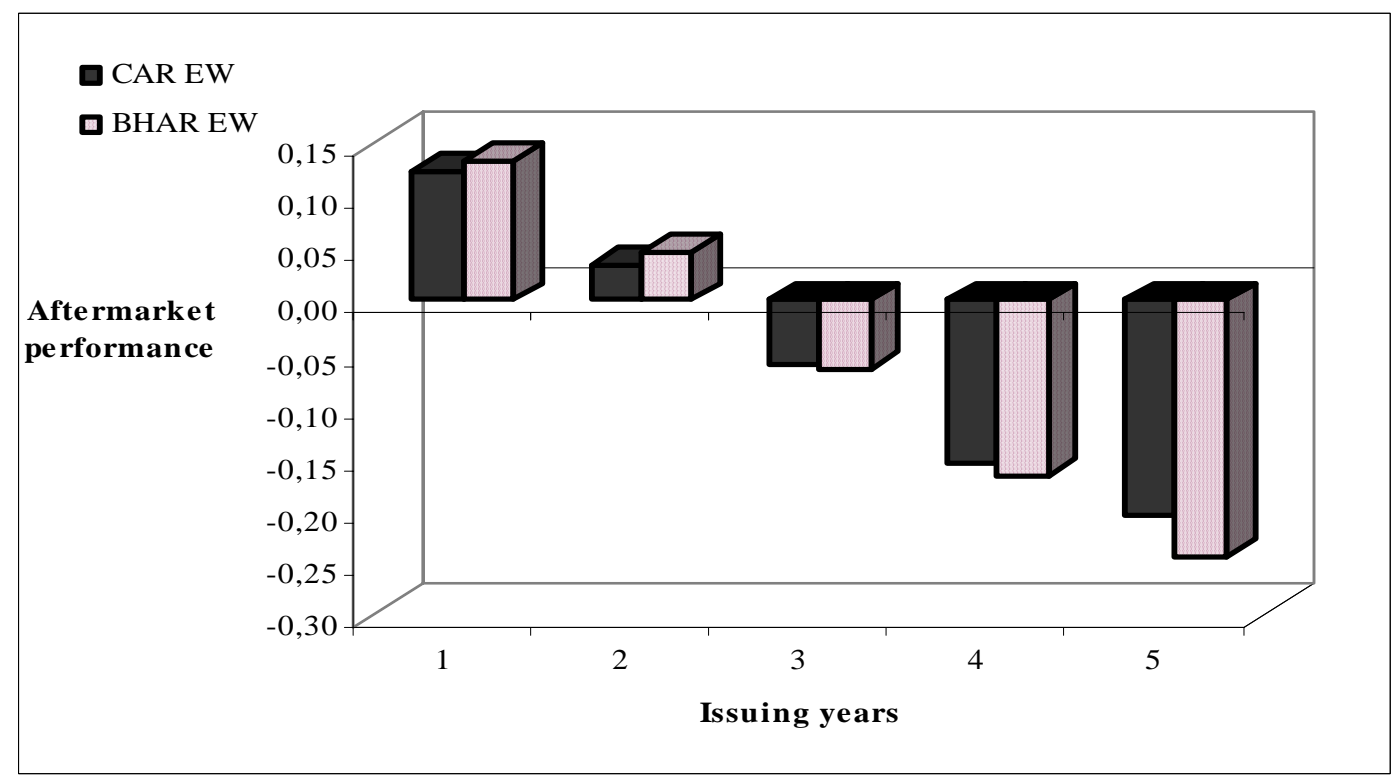


Figure 3 Cumulative abnormal returns (CAR) and buy-and-hold abnormal returns(BHAR). The sample consists of 445 Canadian IPOs by firms subsequently listed on the Toronto Stock Exchange, the Montreal Exchange, the Vancouver Exchange and the Alberta Exchange, from January 1991 through December 1998. The aftermarket performance is measured from the issue price on value weighted base.

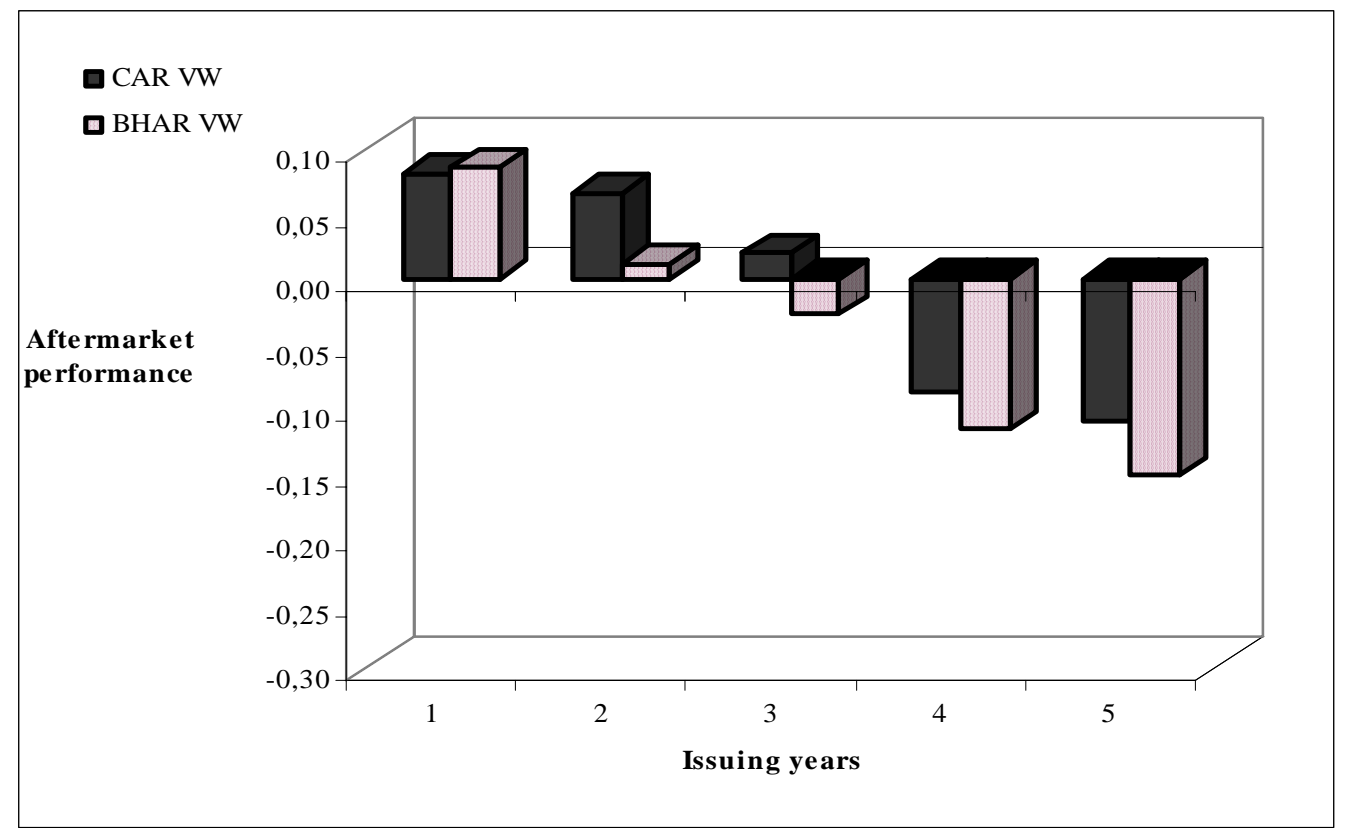

Figure 4 Cumulative abnormal returns (CAR). The sample consists of 445 Canadian IPOs by firms subsequently listed on the Toronto Stock Exchange, the Montreal Exchange, the Vancouver Exchange and the Alberta Exchange, from January 1991 through December 1998. The aftermarket performance is measured from the first closing market price. CAR VW is the weighted value cumulative abnormal returns and the CAR EW is the equally weighted cumulative abnormal returns.

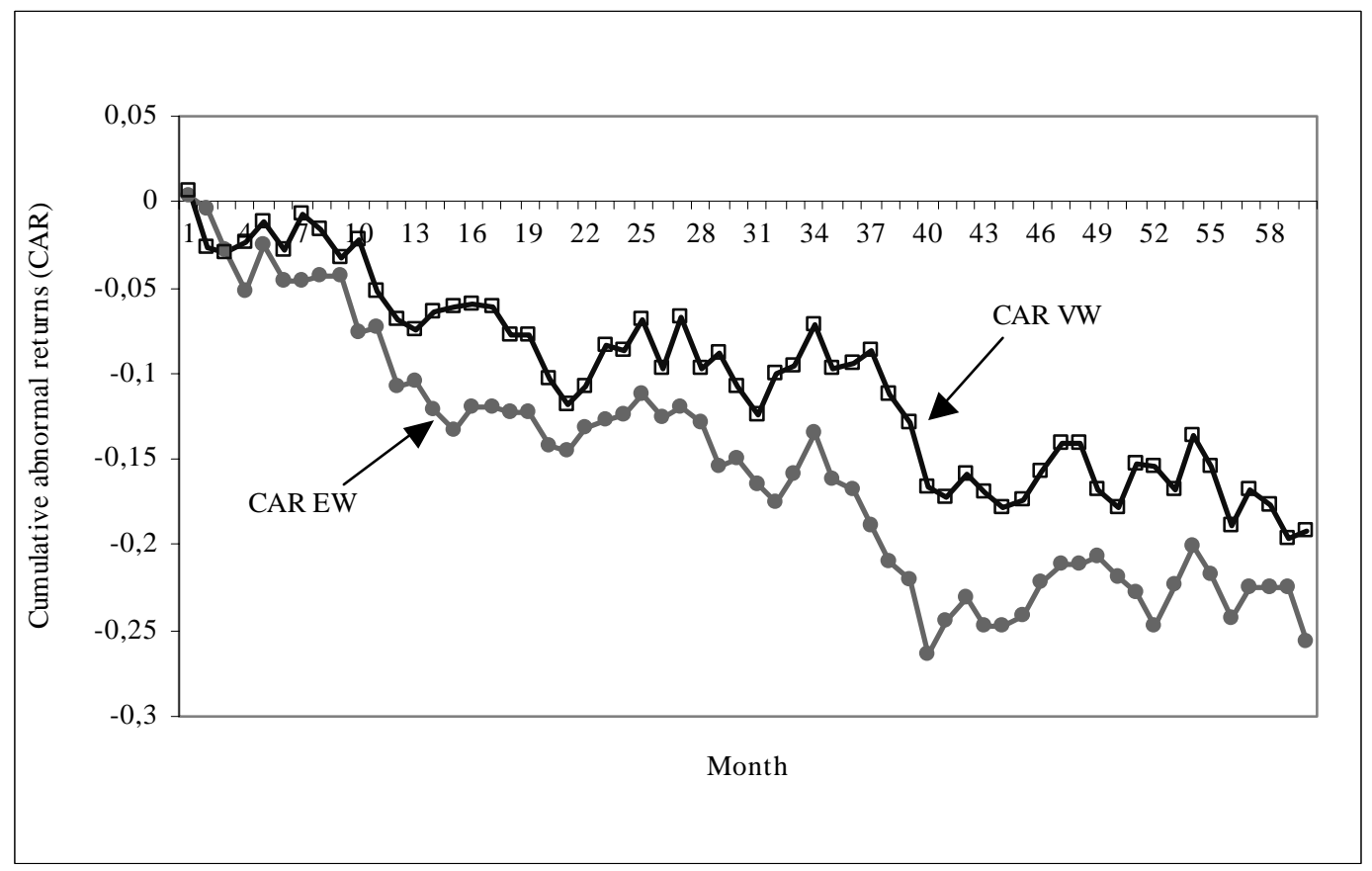


Figure 5 Cumulative abnormal returns (CAR) and buy-and-hold abnormal returns (BHAR). The sample consists of 445 Canadian IPOs by firms subsequently listed on the Toronto Stock Exchange, the Montreal Exchange, the Vancouver Exchange and the Alberta Exchange, from January 1991 through December 1998. The aftermarket performance is measured from the first closing market price on equally weighted base.

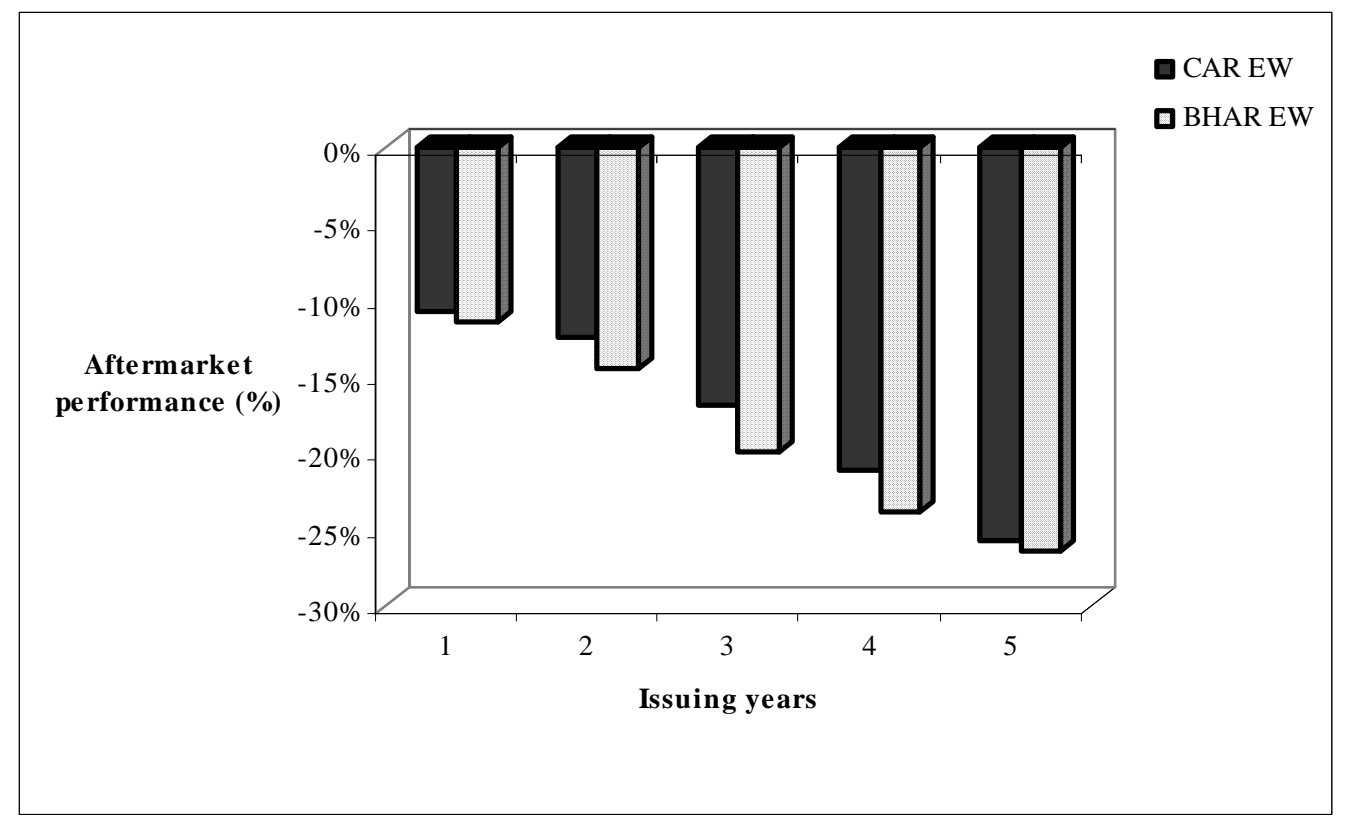

Figure 6 Cumulative abnormal returns (CAR) and buy-and-hold abnormal returns (BHAR). The sample consists of 445 Canadian IPOs by firms subsequently listed on the Toronto Stock Exchange, the Montreal Exchange, the Vancouver Exchange and the Alberta Exchange, from January 1991 through December 1998. The aftermarket performance is measured from the first closing market price on value weighted base.

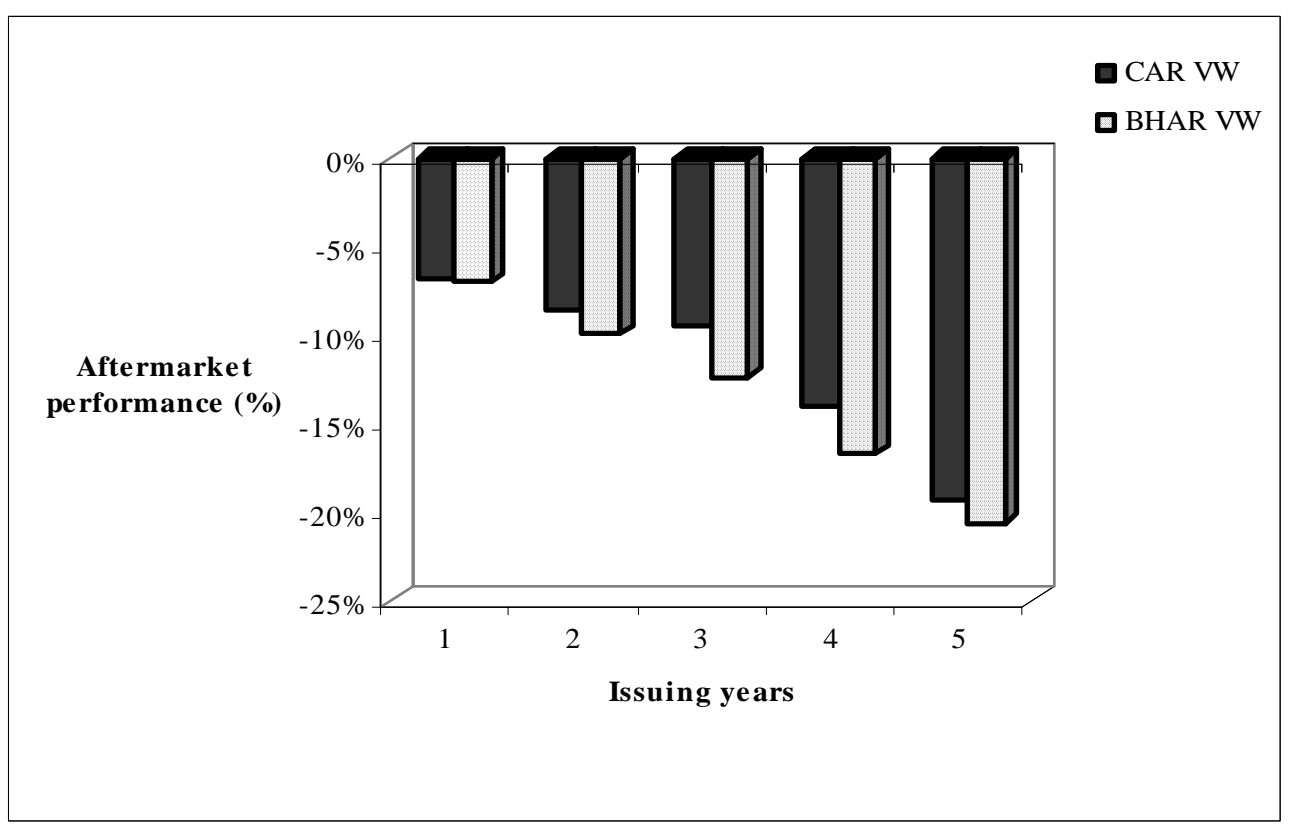


Figure 7 Cumulative abnormal returns (CAR). The sample consists of 445 Canadian IPOs by firms subsequently listed on the Toronto Stock Exchange, the Montreal Exchange, the Vancouver Exchange and the Alberta Exchange, from January 1991 through December 1998. The aftermarket performance is measured from the first closing market price and from issue price on equally weighted base (EW).

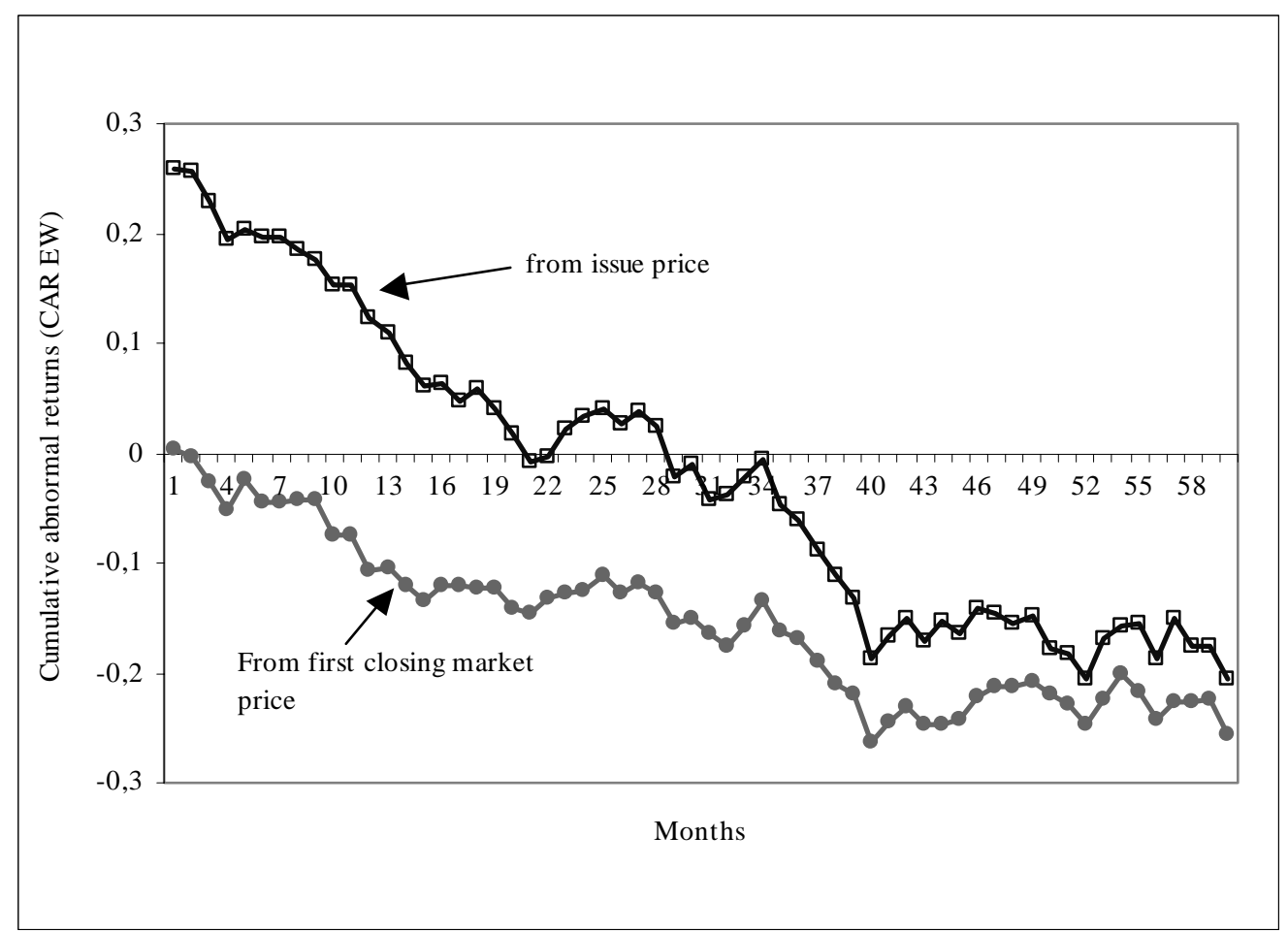

Figure 8 Cumulative abnormal returns (CAR). The sample consists of 445 Canadian IPOs by firms subsequently listed on the Toronto Stock Exchange, the Montreal Exchange, the Vancouver Exchange and the Alberta Exchange, from January 1991 through December 1998. The aftermarket performance is measured from the first closing market price and from issue price on value weighted base $(\mathrm{VW})$.

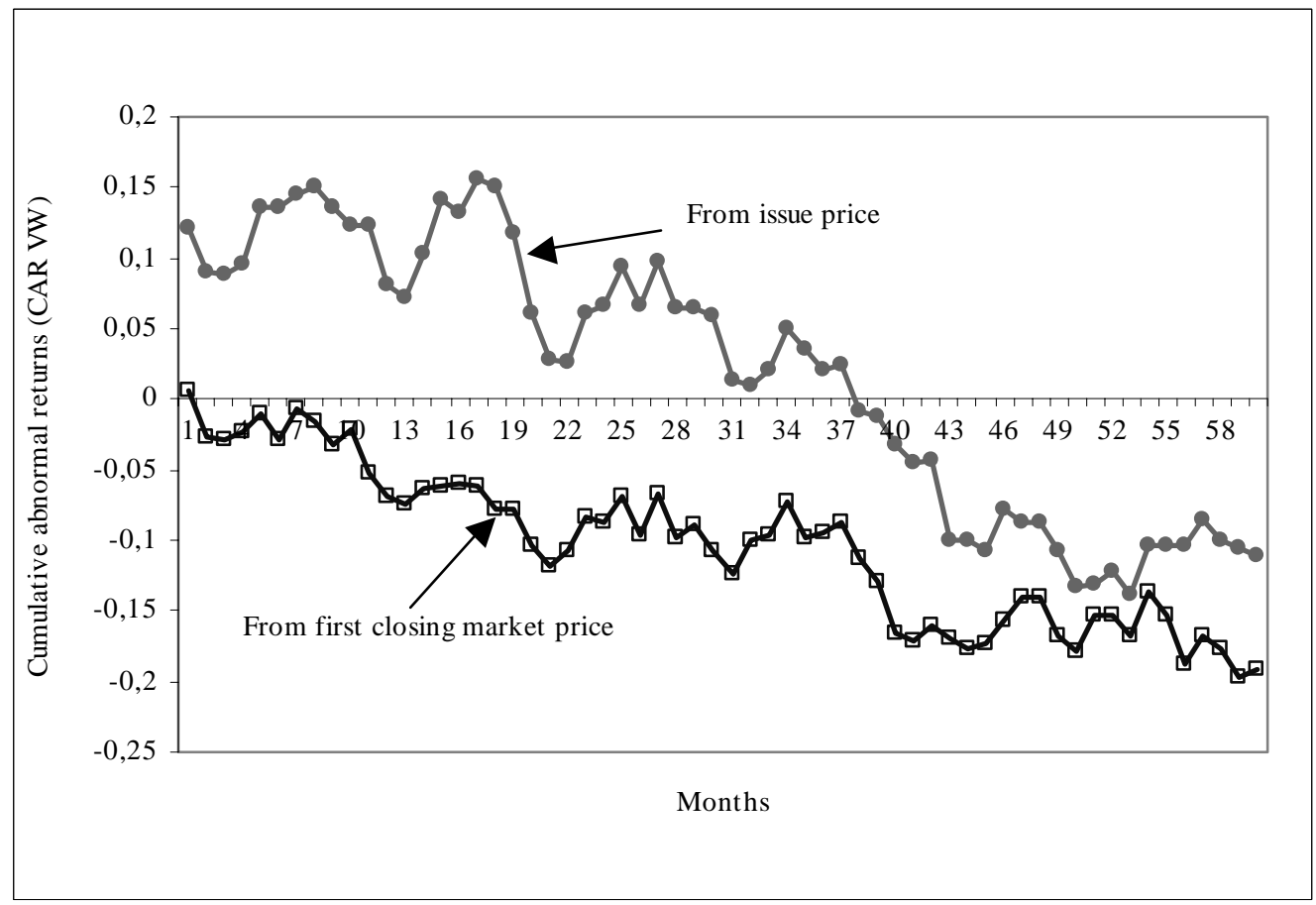


Figure 9 Buy-and-hold abnormal returns (BHAR). The sample consists of 445 Canadian IPOs by firms subsequently listed on the Toronto Stock Exchange, the Montreal Exchange, the Vancouver Exchange and the Alberta Exchange, from January 1991 through December 1998. The aftermarket performance is measured from the first closing market price and from issue price on equally weighted base (EW).

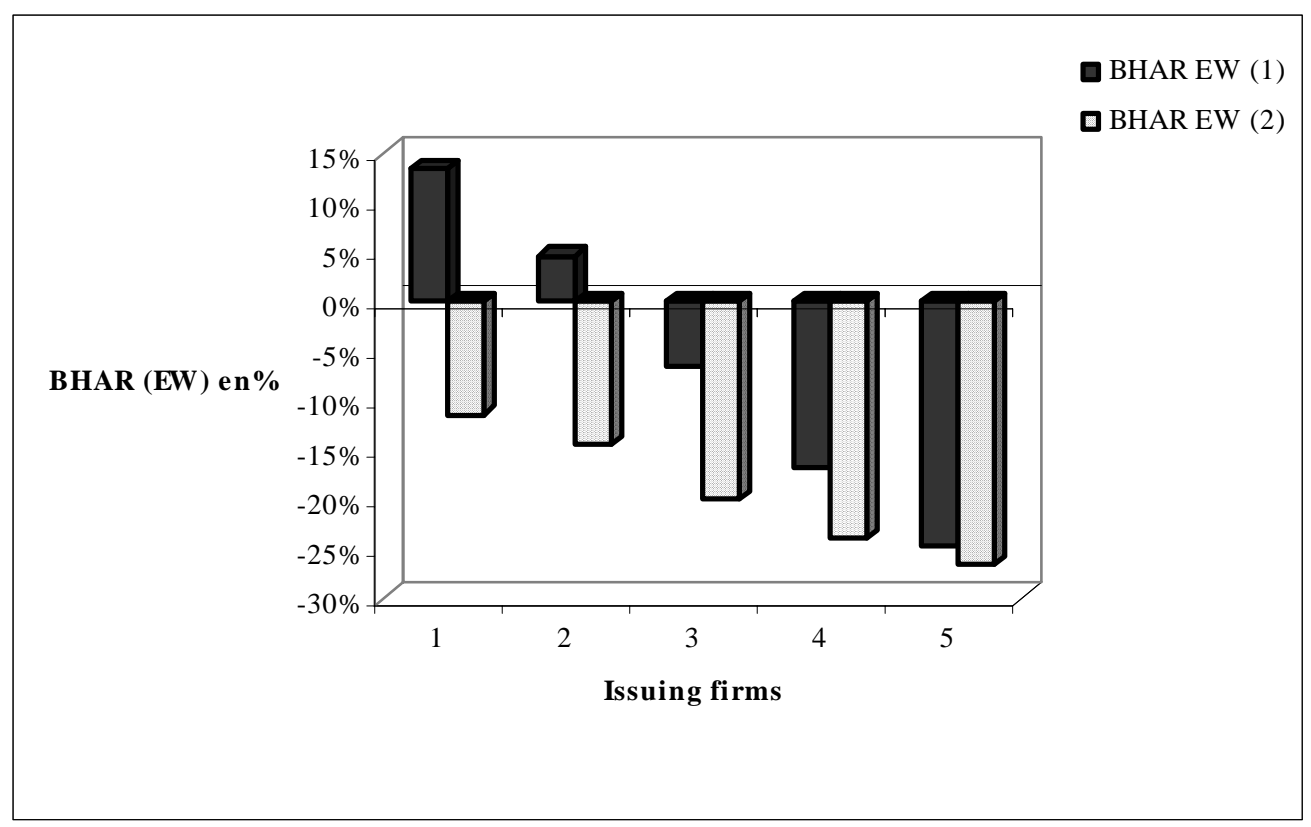

Figure 10 Buy-and-hold abnormal returns (BHAR). The sample consists of 445 Canadian IPOs by firms subsequently listed on the Toronto Stock Exchange, the Montreal Exchange, the Vancouver Exchange and the Alberta Exchange, from January 1991 through December 1998. The aftermarket performance is measured from the first closing market price and from issue price on value weighted base (VW).

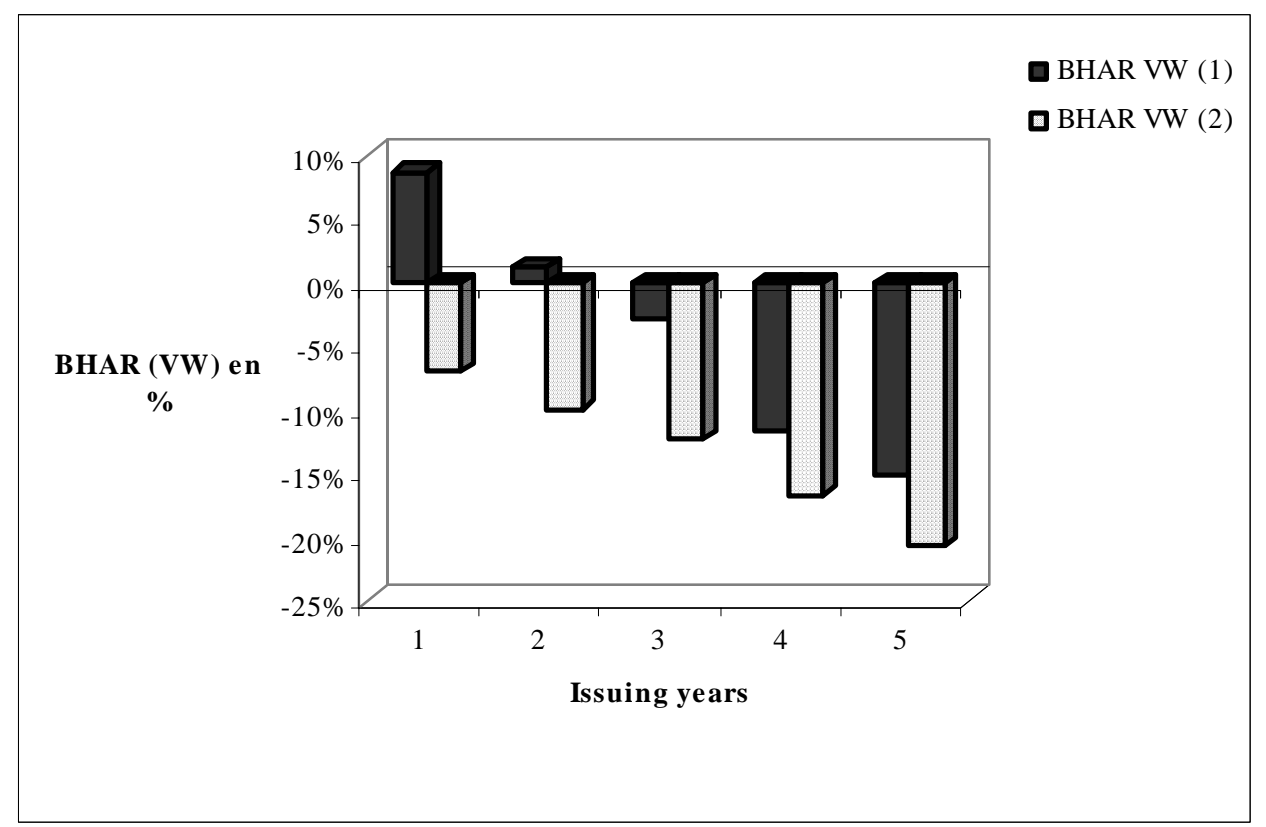


Table 1

International Evidence on the aftermarket performance of IPOs. The aftermarket performance is measured from the first closing market price following the formula : $100 *\left[\left(1+R_{i p o, T}\right) /\left(1+R_{m, T}\right)\right]-100$, where $R_{\text {ipo,T }}$ is the average total return on the IPOs from from the market price shortly after trading commences until the earlier of the de-listing date or 3 years; $\mathrm{R}_{\mathrm{m}, \mathrm{T}}$ is the average of either the market return or matching-firm returns over the same interval.

${ }^{a}$ Jog use two reference portfolios : TSE 300 Index and TSE-Western Index.

${ }^{b} \mathrm{t}=21$ days. This first month consists of event days 2-22, etc.

\begin{tabular}{llccc}
\hline \multicolumn{1}{c}{ Country } & \multicolumn{1}{c}{ Author (s) } & Number of IPOs & Issuing years & $\begin{array}{c}\text { Aftermarket } \\
\text { performance* }\end{array}$ \\
\hline Germany & Ljungqvist & 145 & $1970-90$ & $-12,1 \%$ \\
Australia & Lee, Taylor \& & 266 & $1976-89$ & $-46,5 \%$ \\
& Walter & & & \\
Austria & Aussenegg & 57 & $1965-93$ & $-27,3 \%$ \\
Brazil & Aggarwal, Leal \& & 62 & $1980-90$ & $-47,0 \%$ \\
& Hernandez & & & \\
Canada & Jog & 130 & $1971-92$ & $-35,15 \%-43,66 \%$ \\
& Our analysis & 445 & $1991-98$ & $-16,86 \%$ \\
Chili & Aggarwal, Leal \& & 28 & $1982-90$ & $-23,7 \%$ \\
& Hernandez & & & \\
Korea & Kim, Krinsky \& Lee & 99 & $1985-88$ & $+2,0 \%$ \\
United-States & Loughran \& Ritter & 4,753 & $1970-90$ & $-20,0 \%$ \\
Finland & Keloharju & 79 & $1984-89$ & $-21,1 \%$ \\
Japan & Cai \& Wei & 172 & $1971-90$ & $-27,0 \%$ \\
United Kingdom & Levis & 712 & $1980-88$ & $-8,1 \%$ \\
New Zealand & Michael Firth & 143 & $1979-87$ & $-10,00 \%$ \\
Sweden & Loughran, Ritter \& & 162 & $1980-90$ & $+1,2 \%$ \\
& Rydqvist & & & \\
\hline \hline
\end{tabular}

Table 2

Distribution of IPOs by year. The sample consists of 445 Canadian IPOs by firms subsequently listed on the Toronto Stock Exchange, the Montreal Exchange, the Vancouver Exchange and the Alberta Exchange, from January 1991 through December 1998.

\begin{tabular}{ccc}
\hline \hline Year & Number of IPOs & Proceeds (millions \$) \\
\hline 1991 & 11 & $1044,6 \$$ \\
1992 & 25 & $1437,47 \$$ \\
1993 & 78 & $2451,4 \$$ \\
1994 & 70 & $2203,7 \$$ \\
1995 & 41 & $442,8 \$$ \\
1996 & 85 & $1754,4 \$$ \\
1997 & 88 & $3297,83 \$$ \\
1998 & 47 & $2025,6 \$$ \\
Total & 445 & $14657,9 \$$ \\
\hline \hline
\end{tabular}


Table 3

Distribution of IPOs by province. The sample consists of 445 Canadian IPOs by firms subsequently listed on the Toronto Stock Exchange, the Montreal Exchange, the Vancouver Exchange and the Alberta Exchange, from January 1991 through December 1998. **Others present the following provinces: Manitoba, Saskatchewan, Prince Edward's Islands, Newfoundland and Yukon. We excluded the Junior Capital Pool IPOs.

\begin{tabular}{lcc}
\hline \hline \multicolumn{1}{c}{ Province } & Number of IPOs & Proceeds (millions \$) \\
\hline Alberta & 76 & $1016,3 \$$ \\
Ontario & 170 & $8148,3 \$$ \\
British-Columbia & 127 & $1160,3 \$$ \\
Québec & 48 & $2196,3 \$$ \\
Autres** & 24 & $2072,7 \$$ \\
Total & 445 & $14657,9 \$$ \\
\hline \hline
\end{tabular}

Table 4

Distribution of IPOs by industry. The sample consists of 445 Canadian IPOs by firms subsequently listed on the Toronto Stock Exchange, the Montreal Exchange, the Vancouver Exchange and the Alberta Exchange, from January 1991 through December 1998. **Others present the following sectors or industries : public services, transport, agriculture, conglomerates, film production and other.

\begin{tabular}{lcc}
\hline \hline \multicolumn{1}{c}{ Industry or secteur } & Number of IPOs & Proceeds (millions \$) \\
\hline Mining & 102 & $1644,1 \$$ \\
Oil \& gas & 54 & $1604,55 \$$ \\
Production & 84 & $3927,98 \$$ \\
Technology & 86 & $2838,06 \$$ \\
Financial services & 18 & $590,27 \$$ \\
Real estate & 11 & $537,8 \$$ \\
Biotech/Pharmaceutical products & 22 & $423,15 \$$ \\
Communications and media & 17 & $1254,4 \$$ \\
Merchandising & 14 & $445,06 \$$ \\
Other** & 37 & $1393 \$$ \\
Full sample & 445 & $14657,9 \$$ \\
\hline \hline
\end{tabular}




\section{Table 5}

Cumulatif Abnormal Returns (CAR). The sample consists of 445 Canadian IPOs by firms subsequently listed on the Toronto Stock Exchange, the Montreal Exchange, the Vancouver Exchange and the Alberta Exchange, from January 1991 through December 1998.

CAR from month q to month $\mathrm{s}$ is defined : $\mathrm{CAR}_{\mathrm{qs}}=\sum_{t=q}^{s} A R_{t}$ where $\mathrm{AR}_{\mathrm{t}}=1 / \mathrm{n}_{\mathrm{t}} \sum_{i=1}^{n_{t}} A R_{i t}$ and $\mathrm{AR}_{\mathrm{it}}=\mathrm{R}_{\mathrm{it}}-\mathrm{R}_{\mathrm{mt}}$ is the monthly abnormal return for firm $i$ during the month $t$ where $R_{i t}$ is the return of the firm $i$ during the month and $R_{m t}$ is the return on the benchmark during the corresponding time period.

The statistical test for the $\mathrm{CAR}_{1 \mathrm{t}}$ is: $\mathrm{t}_{\mathrm{CAR} 1, \mathrm{t}}=\mathrm{CAR}_{1, \mathrm{t}} * \sqrt{n_{t}} / \sqrt{\left[\mathrm{t}^{*} \mathrm{var}+2 *(\mathrm{t}-1) * \operatorname{cov}\right]}$ where var is the average of the cross-sectional variations over 60 months of the $\mathrm{ar}_{\mathrm{it}}$, and var is the first order auto-covariance of the $\mathrm{AR}_{\mathrm{t}}$ series. CARs include initial returns and are equally weighted (EW) and value weighted (VW).

\begin{tabular}{cccccc}
\hline Month & Number of IPOs & CAR $_{\mathrm{t}}(\mathrm{EW})$ & $\mathrm{t}$-statistic & $\mathrm{CAR}_{\mathrm{t}}(\mathrm{VW})$ & t-statistic \\
\hline 1 & 443 & 0,2576 & 16,99 & 0,1221 & 57,00 \\
2 & 442 & 0,2568 & 11,96 & 0,0894 & 28,77 \\
3 & 438 & 0,2281 & 8,64 & 0,0879 & 19,28 \\
4 & 434 & 0,1932 & 6,31 & 0,0959 & 13,61 \\
5 & 432 & 0,2027 & 5,91 & 0,1353 & 12,50 \\
6 & 427 & 0,1964 & 5,19 & 0,1353 & 10,86 \\
7 & 420 & 0,1967 & 4,78 & 0,1443 & 9,89 \\
8 & 416 & 0,1846 & 4,17 & 0,1512 & 8,59 \\
9 & 408 & 0,1766 & 3,73 & 0,1361 & 7,63 \\
10 & 403 & 0,1519 & 3,02 & 0,1239 & 6,17 \\
11 & 397 & 0,1539 & 2,90 & 0,1223 & 5,89 \\
12 & 391 & 0,1236 & 2,21 & 0,0811 & 4,49 \\
24 & 290 & 0,0344 & 0,38 & 0,0660 & 0,75 \\
36 & 217 & $-0,0615$ & $-0,47$ & 0,0201 & $-0,94$ \\
48 & 163 & $-0,1554$ & $-0,90$ & $-0,0878$ & $-1,78$ \\
60 & 101 & $-0,2065$ & $-0,84$ & $-0,1102$ & $-1,67$ \\
\hline \hline
\end{tabular}




\section{Table 6}

Cumulatif Abnormal Returns (CAR). The sample consists of 445 Canadian IPOs by firms subsequently listed on the Toronto Stock Exchange, the Montreal Exchange, the Vancouver Exchange and the Alberta Exchange, from January 1991 through December 1998. CAR from month q to month $\mathrm{s}$ is defined : $\mathrm{CAR}_{\mathrm{qs}}=\sum_{t=q}^{s} A R_{t} \mathrm{where}_{\mathrm{AR}}=$ $1 / \mathrm{n}_{\mathrm{t}} \sum_{i=1}^{n t} A R_{i t}$ and $\mathrm{AR}_{\mathrm{it}}=\mathrm{R}_{\mathrm{it}}-\mathrm{R}_{\mathrm{mt}}$ is the monthly abnormal return for firm $\mathrm{i}$ during the month $\mathrm{t}$ where $\mathrm{R}_{\mathrm{it}}$ is the return of the firm $\mathrm{i}$ during the month and $\mathrm{R}_{\mathrm{mt}}$ is the return on the benchmark during the corresponding time period.

the statistical test for the $\mathrm{CAR}_{1 \mathrm{t}}$ is: $\mathrm{t}_{\mathrm{CAR} 1, \mathrm{t}}=\mathrm{CAR}_{1, \mathrm{t}} * \sqrt{n_{t}} / \sqrt{\left[\mathrm{t}^{*} \text { var }+2 *(\mathrm{t}-1) * \operatorname{cov}\right]}$ where var is the average of the cross-sectional variations over 60 months of the $a_{i t}$, and var is the first order auto-covariance of the $A R_{t}$ series. CARs exclude the initial returns and equally weighted (EW) and value weighted (VW).

\begin{tabular}{cccccc}
\hline Month & Number of IPOs & CAR $_{\mathrm{t}}(\mathrm{EW})$ & $\mathrm{t}$-statistic & $\mathrm{CAR}_{\mathrm{t}}(\mathrm{VW})$ & $\mathrm{t}$-statistic \\
\hline 1 & 442 & 0,0042 & 0,28 & 0,0065 & 2,46 \\
2 & 438 & $-0,0040$ & $-0,19$ & $-0,0269$ & $-5,25$ \\
3 & 434 & $-0,0275$ & $-1,05$ & $-0,0290$ & $-4,26$ \\
4 & 432 & $-0,0520$ & $-1,72$ & $-0,0230$ & $-2,82$ \\
5 & 426 & $-0,0251$ & $-0,74$ & $-0,0110$ & $-1,18$ \\
6 & 419 & $-0,0455$ & $-1,21$ & $-0,0287$ & $-2,76$ \\
7 & 415 & $-0,0456$ & $-1,12$ & $-0,0071$ & $-0,62$ \\
8 & 408 & $-0,0425$ & $-0,97$ & $-0,0155$ & $-1,25$ \\
9 & 403 & $-0,0431$ & $-0,92$ & $-0,0319$ & $-2,40$ \\
10 & 397 & $-0,0756$ & $-1,52$ & $-0,0217$ & $-1,53$ \\
11 & 391 & $-0,0737$ & $-1,40$ & $-0,0528$ & $-3,52$ \\
12 & 381 & $-0,1079$ & $-1,96$ & $-0,0684$ & $-4,30$ \\
24 & 281 & $-0,1243$ & $-1,35$ & $-0,0868$ & $-3,27$ \\
36 & 205 & $-0,1686$ & $-1,28$ & $-0,0939$ & $-2,45$ \\
48 & 159 & $-0,2120$ & $-1,23$ & $-0,1402$ & $-2,79$ \\
60 & 98 & $-0,2568$ & $-1,04$ & $-0,1923$ & $-2,68$ \\
\hline \hline
\end{tabular}




\section{Table 7}

Buy-and-hold abnormal returns (BHARs). The sample consists of 445 Canadian IPOs by firms subsequently listed on the Toronto Stock Exchange, the Montreal Exchange, the Vancouver Exchange and the Alberta Exchange, from January 1991 through December 1998.

The buy-and-hold abnormal return (BHAR) is defined as follows:

$\mathrm{BHAR}_{\mathrm{i}, \mathrm{T}}=\left[\Pi_{t=1}^{T}\left(1+r_{i t}\right)-1\right]-\left[\Pi_{t=1}^{T}\left(1+r_{m t}\right)-1\right]$ where $\mathrm{T}=60$ months or the delisted date of the stock, $\mathrm{r}_{\mathrm{it}}$ is the return of the firm $i$ during the month and $r_{m t}$ is the return on the benchmark during the corresponding time period. BHAR(1) is measured from the issue price and BHAR(2) is measured from the first closing market price. EW is equally weighted base and VW is value weighted base. To test the null hypothesis of zero mean buy-and-hold return, we use the skewness-adjusted $\mathrm{t}$ statistic. The $\mathrm{t}$ statistic is defined as:

$\mathrm{t}=\sqrt{\mathrm{n}} \times\left(\mathrm{S}+\frac{1}{3} \hat{\gamma} \mathrm{S}^{2}+\frac{1}{6 \mathrm{n}} \hat{\gamma}\right)$ where $\mathrm{S}=\frac{\text { Mean(BHAR })_{\mathrm{t}}}{\sigma(\mathrm{BHAR}) \mathrm{t}} ; \mathrm{t}=12,24,36,48$ et 60 months and $\hat{\gamma}$ is an estimate of the coefficient of skewness. * significant at $1 \%, * *$ significant at $5 \%$ and $* * *$ significant at $10 \%$.

\begin{tabular}{c|c|c|c|c}
\hline \hline Method & \multicolumn{2}{|c|}{ BHAR $(1)$} & \multicolumn{2}{c}{ BHAR $(2)$} \\
\hline \hline Years post-IPO & EW & VW & EW & VW \\
\hline \hline 1 year & 0,1334 & $0,0861^{* * *}$ & $-0,1145$ & $-0,0697 * * *$ \\
2 year & 0,0456 & 0,0113 & $-0,1441$ & $-0,099^{*}$ \\
3 year & $-0,0659$ & $-0,0277$ & $-0,1996$ & $-0,1232$ \\
4 year & $-0,1681$ & $-0,1163$ & $-0,2394$ & $-0,1669$ \\
5 year & $-0,2466$ & $-0,1516$ & $-0,265$ & $-0,2061$ \\
\hline \hline
\end{tabular}


Table 8

BHARs and subsample characteristics. The sample consists of 445 Canadian IPOs by firms subsequently listed on the Toronto Stock Exchange, the Montreal Exchange, the Vancouver Exchange and the Alberta Exchange, from January 1991 through December $1998 .^{+}$Other present the following sectors or industries : public services, transport, agriculture, film production, conglomerates and other. BHARs exclude initial returns and are equally weighted. Underpricing is calculated as : (mean of the closing market price of the five first days of trading - issue price)/ issue price. ${ }^{*}$ significant at $1 \%, * *$ significant at $5 \%$ and $* * *$ significant at $10 \%{ }^{\mathrm{D}} \mathrm{t}$-test for differences in average initial return between the following subgroups : ( hot IPOs and cold IPOs ) significant at $5 \%$ level.

\begin{tabular}{|c|c|c|c|c|c|c|}
\hline Échantillon & $\begin{array}{c}\text { Mois } 12 \\
(\%)\end{array}$ & $\begin{array}{c}\text { Mois } 24 \\
(\%)\end{array}$ & $\begin{array}{c}\text { Mois } 36 \\
(\%)\end{array}$ & $\begin{array}{c}\text { Mois } 48 \\
(\%)\end{array}$ & $\begin{array}{c}\text { Mois } 60 \\
(\%)\end{array}$ & $\begin{array}{c}\text { Underpricing } \\
(\%)\end{array}$ \\
\hline BHAR & $-11,45$ & $-14,41$ & $-19,96$ & $-23,94$ & $-26,5$ & $20,57 \%$ \\
\hline Full sample & 440 & 389 & 286 & 210 & 166 & 445 \\
\hline Biotech / pharmaceutical products & $-16,37$ & $-26,35 * * *$ & $-38,20 *$ & $-29,00$ & $-16,20$ & $17,03 \%$ \\
\hline Number & 22 & 20 & 16 & 10 & 8 & \\
\hline Communications and média & $-17,70 * * *$ & $-23,85$ & $-12,69$ & $-2,65$ & 3,82 & $-4,66 \%$ \\
\hline Number & 16 & 16 & 12 & 11 & 9 & \\
\hline Financial services & 5,83 & 13,33 & 25,09 & 21,62 & 22,88 & $1,31 \%$ \\
\hline Number & 19 & 14 & 10 & 6 & 5 & \\
\hline Mining & $-21,14 *$ & $-17,82 * * *$ & $-18,92 * * *$ & $-31,31 * *$ & $-25,19 *$ & $35,71 \% *$ \\
\hline Number & 101 & 89 & 64 & 49 & 34 & \\
\hline Oil \& gas & $-14,60$ & $-16,28$ & $-35,90$ & $-27,31$ & $-37,94$ & $29,04 \% *$ \\
\hline Number & 53 & 49 & 34 & 24 & 20 & \\
\hline Other $^{+}$ & $-17,14 * * *$ & $-14,84$ & $-19,11$ & $-16,90$ & $-21,99$ & $22,37 \% *$ \\
\hline Number & 36 & 29 & 25 & 12 & 8 & \\
\hline Production & $-11,86^{*}$ & $-17,15$ & $-26,28$ & $-28,19$ & $-25,03$ & $11,11 \%$ \\
\hline Number & 84 & 77 & 59 & 48 & 39 & \\
\hline Real estate & $-5,73$ & $-19,42$ & $-26,89$ & $-24,66$ & $-32,99$ & $16,9 \%$ \\
\hline Observations & 11 & 9 & 5 & 4 & 2 & \\
\hline Merchandising & $-4,25$ & $-2,04$ & $-1,2$ & $-0,16$ & $-2,14$ & $-1,9 \%$ \\
\hline Number & 14 & 13 & 11 & 11 & 11 & \\
\hline Technology & 2,17 & $-16,34$ & $-22,15$ & $-22,98 * *$ & $-20,90^{*}$ & $19,77 \% *$ \\
\hline Number & 84 & 73 & 50 & 35 & 30 & \\
\hline Proceeds $\leq 10 \mathrm{M} \$$ & $-22,85^{*}$ & $-27,53^{*}$ & $-21,87^{*}$ & $-42,58^{*}$ & $-44,86^{*}$ & $38,56 \% *$ \\
\hline Number & 235 & 209 & 141 & 96 & 72 & \\
\hline Proceeds $>10 \mathrm{M} \$$ & 1,8 & $-2,7$ & $-10,93$ & $-7,9$ & $-3,1$ & $0,06 \%$ \\
\hline Number & 205 & 180 & 145 & 114 & 94 & \\
\hline Hot period & $-13,52 *$ & $-15,34^{*}$ & $-18,06^{* * *}$ & $-30,12^{* * * *}$ & $-39,08 * \mathrm{D}$ & $22,03 \% *$ \\
\hline Number & 318 & 313 & 213 & 138 & 133 & \\
\hline Cold period & $-6,40$ & $-6,56$ & $-10,41$ & $-9,46$ & $-4,6$ & $16,77 \% *$ \\
\hline Number & 112 & 76 & 73 & 72 & 33 & \\
\hline Overpriced IPOs & $-3,35$ & $-13,26$ & $-11,14$ & $-14,25$ & $-6,73$ & $-25,44 \% *$ \\
\hline Number & 120 & 114 & 91 & 69 & 56 & \\
\hline Underpriced IPOs & $-14,35^{*}$ & $-17,23^{*}$ & $-18,75^{*}$ & $-28,66^{*}$ & $-28,61^{*}$ & $41,79 \% *$ \\
\hline Number & 320 & 275 & 195 & 141 & 110 & \\
\hline
\end{tabular}


Table 9

Performance categorized by the year of issue. The sample consists of 445 Canadian IPOs by firms subsequently listed on the Toronto Stock Exchange, the Montreal Exchange, the Vancouver Exchange and the Alberta Exchange, from January 1991 through December 1998. BHARs exclude initial returns and are equally weighted. * significant at $1 \%, * *$ significant at $5 \%$ and $* * *$ significant at $10 \%$.

\begin{tabular}{cccccccc}
\hline \hline Year & $\begin{array}{c}\text { Number of } \\
\text { IPOs }\end{array}$ & $\begin{array}{c}\text { Proceed } \\
\text { (in millions \$CAN) }\end{array}$ & $\begin{array}{c}\text { BHAR } \\
\text { 1-year }\end{array}$ & $\begin{array}{c}\text { BHAR } \\
\text { 2-year }\end{array}$ & $\begin{array}{c}\text { BHAR } \\
\text { 3-year }\end{array}$ & $\begin{array}{c}\text { BHAR } \\
\text { 4-year }\end{array}$ & $\begin{array}{c}\text { BHAR } \\
\text { 5-year }\end{array}$ \\
\hline 1991 & 11 & $1044,6 \$$ & $-3,3 \%$ & $-5,3 \%$ & $-3,28 \%$ & $-7,58 \%$ & $-7 \%$ \\
1992 & 25 & $1437,47 \$$ & $-1,6 \%$ & $0,19 \%$ & $-9,9 \%$ & $-10,48 \%$ & $-12,54 \%^{* * *}$ \\
1993 & 78 & $2451,4 \$$ & $-4,16 \% *$ & $-7,03 \% *$ & $-13,29 \%$ & $-12,30 \% *$ & $-14,71 \%^{*}$ \\
1994 & 70 & $2203,7 \$$ & $-11,99 \%$ & $-16,34 \%$ & $-32,86 \%$ & $-30,72 \%$ & $-33,85 \%^{* * *}$ \\
1995 & 41 & $442,8 \$$ & $-4,44 \%$ & $-10,43 \%$ & $-10,80 \%$ & $-11,92 \% *$ & \\
1996 & 85 & $1754,4 \$$ & $-6,88 \%$ & $-19,39 \% * * *$ & $-23,34 \% *$ & & \\
1997 & 88 & $3297,8 \$$ & $-13,15 \% *$ & $-23,58 \% *$ & & & \\
1998 & 47 & $2025,6 \$$ & $-1,5 \%$ & & & & \\
\hline \hline
\end{tabular}

Table 10

Results of multiple regressions. The sample consists of 445 Canadian IPOs by firms subsequently listed on the Toronto Stock Exchange, the Montreal Exchange, the Vancouver Exchange and the Alberta Exchange, from January 1991 through December 1998. BHARs exclude initial returns and are equally weighted. The regression model has

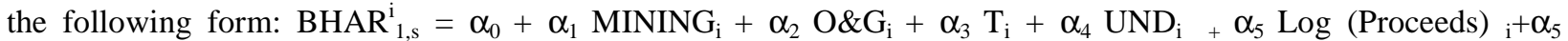
HOT/COLD $+\varepsilon_{\mathrm{is}}$, where $\mathrm{s}$ takes on a value of $12,24,36,48$ or $60, \mathrm{MINING}_{\mathrm{i}}$ takes a value of 1 form mining issues and zero otherwise, $O \& G_{i}$ takes a value of 1 form oil and gas issues and zero otherwise, $T$ takes a value of 1 for technology issues and zero otherwise, $\mathrm{UND}_{\mathrm{i}}$ is the underpricing in stock $\mathrm{i}$, HOT/COLD takes a value of 1 for hot issues (1993,1994, 1996 and 1997) and 0 otherwise (1991, 1992, 1995 and 1995) and Log denotes the natural logarithm. The proceed of the issue is used as a proxy for ex-ante uncertainty. T-value are reported in parentheses. White's consistent covariance matrix is used in estimating standard errors and all t-values are reported on an adjusted basis.

*significant at $1 \%, * *$ significant at $5 \%$ and $* * *$ significant at $10 \%$.

\begin{tabular}{cccccccccc}
\hline \hline & \multicolumn{7}{c}{ Independent Variables } \\
\hline $\begin{array}{c}\text { Dependent } \\
\text { Variable }\end{array}$ & Constant & MINING & O\&G & $\mathrm{T}$ & UND & Proceed & Hot/Cold & $\mathrm{R}^{2}$ adj & IPOs \\
\hline BHAR $(1,12)$ & $-0,78$ & $-0,04$ & $-0,07$ & $-0,03$ & $-0,018$ & 0,11 & $-0,14$ & 0,066 & 440 \\
& $(-3,31)^{* * *}$ & $(-0,65)$ & $(-0,89)$ & $(-0,46)$ & $(-1,12)$ & $(3,598)^{* * *}$ & $(-2,5)^{* *}$ & 6,6 & \\
BHAR $(1,24)$ & $-0,67$ & $-0,21$ & $-0,12$ & $-0,21$ & 0,003 & 0,12 & $-0,31$ & 0,066 & 389 \\
& $(-1,84)^{*}$ & $(-1,91)^{*}$ & $(-0,94)$ & $(-1,92)^{*}$ & $(0.15)$ & $(2,51)^{* *}$ & $(-3,1)^{* * *}$ & 6,6 & \\
BHAR $(1,36)$ & $-0,02$ & $-0,29$ & $-0,05$ & $-0,25$ & 0,006 & 0,02 & $-0,18$ & 0,051 & 286 \\
& $(-0,08)$ & $(-2,63)^{* * *}$ & $(-0,41)$ & $(-2,29)^{* *}$ & $(0,33)$ & $(0,51)$ & $(-1,97)^{* *}$ & 5,1 & \\
BHAR $(1,48)$ & $-0,42$ & $-0,38$ & $-0,48$ & $-0,22$ & 0,02 & 0,09 & $-0,29$ & 0,068 & 210 \\
& $(-0,64)$ & $(-1,98)^{* *}$ & $(-2,14)^{* *}$ & $(-1,17)$ & $(0,19)$ & $(0,98)$ & $(-2,01)^{* *}$ & 6,8 & \\
BHAR $(1,60)$ & $-0,60$ & $-0,17$ & $-0,51$ & $-0,10$ & 0,13 & 0,10 & $-0,29$ & 0,074 & 166 \\
& $(-0,92)$ & $(-0,9)$ & $(-2,4)^{* *}$ & $(-0,61)$ & $(1,08)$ & $(1,22)$ & $(-1,75)^{*}$ & 7,4 & \\
\hline \hline
\end{tabular}




\section{Liste des publications au CIRANO*}

Série Scientifique / Scientific Series (ISSN 1198-8177)

2001s-51 Capital Structure and Risk Management / Karine Gobert

2001s-50 The Underpricing of Initial Public Offerings: Futher Canadian Evidence / Maher Kooli et Jean-Marc Suret

2001s-49 How Innovative Are Canadian Firms Compared to Some European Firms? A Comparative Look at Innovation Surveys / Pierre Mohnen et Pierre Therrien

2001s-48 A Tale of Two Ports / Ngo Van Long et Kar-yiu Wong

2001s-47 Wage Policy of Firms: An Empirical Investigation / Stéphanie Lluis

2001s-46 Forecasting Some Low-Predictability Time Series Using Diffusion Indices / Marc Brisson, Bryan Campbell et John W. Galbraith

2001s-45 The Importance of the Loss Function in Option Pricing / Peter Christoffersen et Kris Jacobs

2001s-44 Let's Get "Real" about Using Economic Data / Peter Christoffersen, Eric Ghysels et Norman R. Swanson

2001s-43 Fragmentation, Outsourcing and the Service Sector / Ngo Van Long, Ray Riezman et Antoine Soubeyran

2001s-42 Nonlinear Features of Realized FX Volatility / John M. Maheu et Thomas H. McCurdy

2001s-41 Job Satisfaction and Quits: Theory and Evidence from the German Socioeconomic Panel / Louis Lévy-Garboua, Claude Montmarquette et Véronique Simonnet

2001s-40 Logique et tests d'hypothèse : réflexions sur les problèmes mal posés en économétrie / Jean-Marie Dufour

2001s-39 Managing IT Outsourcing Risk: Lessons Learned / Benoit A. Aubert, Suzanne Rivard et Michel Patry

2001s-38 Organizational Design of R\&D Activities / Stefan Ambec et Michel Poitevin

2001s-37 Environmental Policy, Public Interest and Political Market / Georges A. Tanguay, Paul Lanoie et Jérôme Moreau

2001s-36 Wealth Distribution, Entrepreneurship and Intertemporal Trade / Sanjay Banerji et Ngo Van Long

2001s-35 Comparaison des politiques de rémunération en fonction des stratégies organisationnelles / Michel Tremblay et Denis Chênevert

2001s-34 Déterminants et efficacité des stratégies de rémunération : Une étude internationale des entreprises à forte intensité technologique / Michel Tremblay, Denis Chênevert et Bruno Sire

* Consultez la liste complète des publications du CIRANO et les publications elles-mêmes sur notre site Internet : 